\title{
PARKS AND PARK FUNDING IN LOS ANGELES: AN EQUITY MAPPING ANALYSIS
}

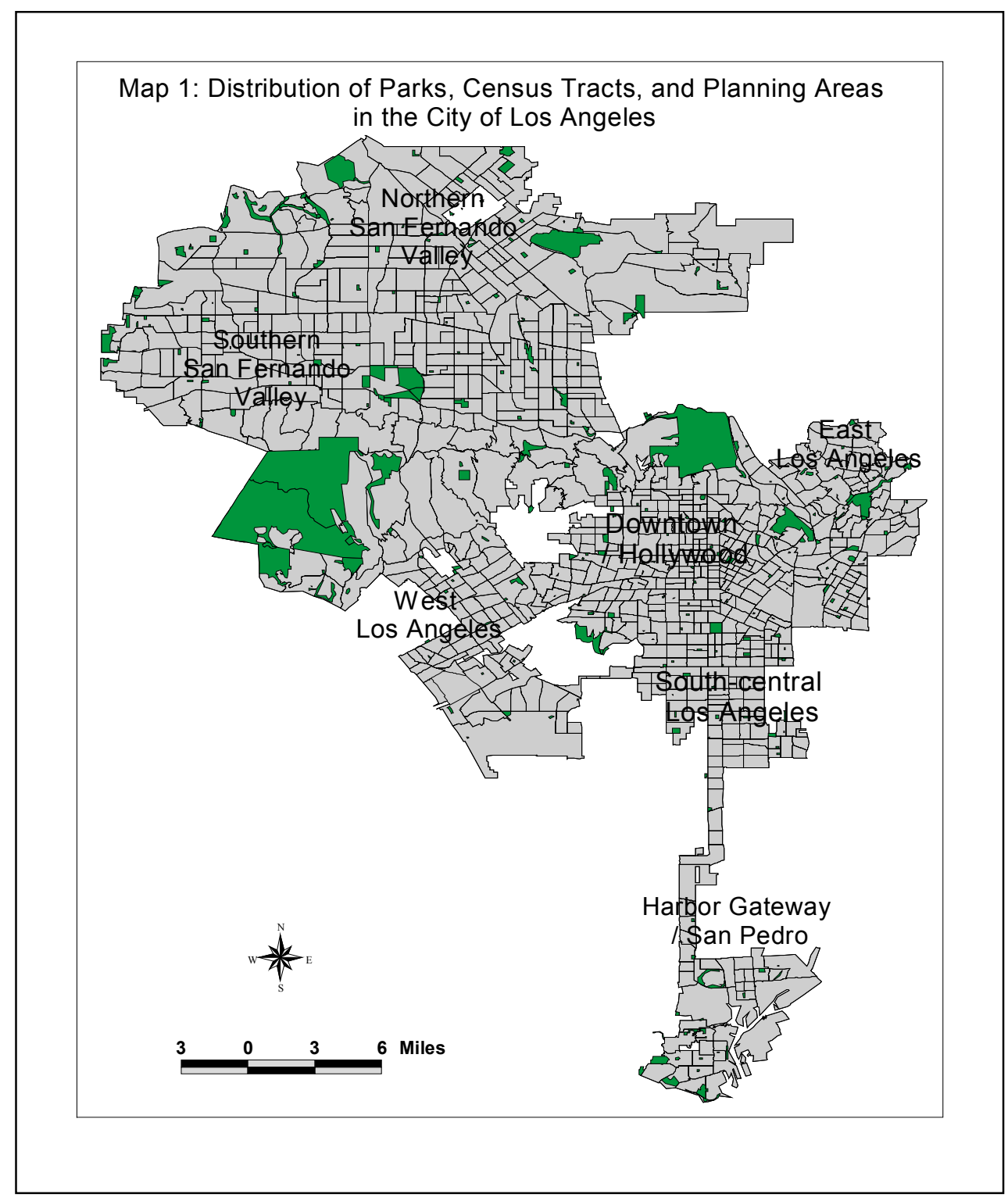

Jennifer Wolch

Sustainable Cities Program

John P. Wilson

GIS Research Laboratory

Jed Fehrenbach

Department of Geography 
Jennifer Wolch is Professor of Geography and a Co-Director of the Sustainable Cities Program at the University of Southern California

John P. Wilson is Professor of Geography and Director of the Department of Geography GIS Research Laboratory at the University of Southern California

Jed Fehrenbach is a senior in Geography at the University of Southern California

(C) May 2002

Sustainable Cities Program

University of Southern California

927 Hellman Way, PIC 200

Los Angeles, CA 90089-0027

www.usc.edu/dept/geography/ESPE

and

GIS Research Laboratory

University of Southern California

3620 S. Vermont Avenue, KAP 416

Los Angeles, CA 90089-0255

www.usc.edu/dept/geography/gislab

Acknowledgments: The authors would like to thank Travis Longcore, Angela Johnson Meszaros, Stephanie Pincetl and Michael Dear for their assistance and advice with this project and Denise Steiner for administrative support. Thanks also to Steve Brackmann and Jamin Johnson for their contributions to an earlier version of this analysis.

This report is available at:

http://www.usc.edu/dept/geography/ESPE

This report would not have been possible without the generous support of The John Randolph Haynes and Dora Haynes Foundation of Los Angeles. 


\section{TABLE OF CONTENTS}

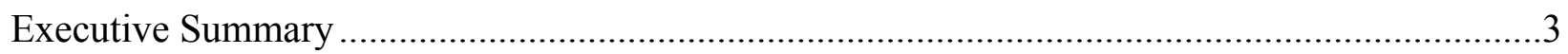



Environmental Justice and Urban Parks in Los Angeles ...............................................................

Funding for LA's Urban Parks and Open Space ……….........................................................

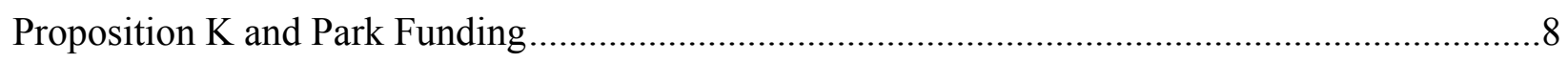

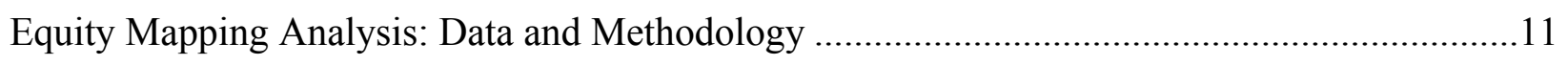

Accessibility of Parks and Recreation Facilities to LA's Children and Youth..............................13

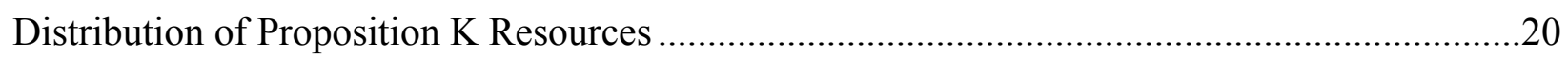

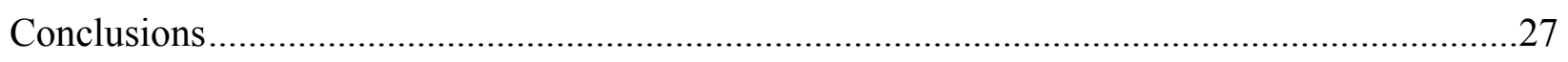

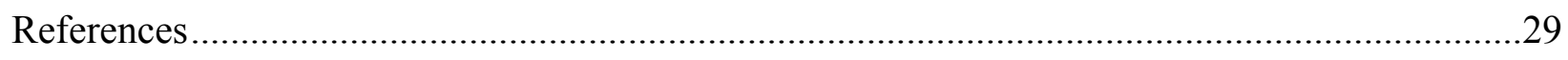




\section{EXECUTIVE SUMMARY}

In 1996, Los Angeles voters passed the park bond measure, Proposition K, to increase and enhance park and recreation space in the city. Using information on the distribution of existing parks in the City of Los Angeles and census data, this report provides a statistical analysis of access to park space enjoyed by children and youth, and by residents according to their race/ethnicity and socioeconomic status. Further, a mapping of Prop. K grant allocations by location reveals the extent to which the distribution of Prop. K funds has increased access to parks for residents most in need of park space.

Our analysis finds that:

- Low-income and concentrated poverty areas as well as neighborhoods dominated by Latinos, African Americans, and Asian-Pacific Islanders, have dramatically lower levels of access to park resources than white dominated areas of the city;

- $\quad$ Prop. K funding patterns often exacerbate rather than ameliorate existing inequalities in park and open space resource distributions in the City of Los Angeles;

- Neighborhoods with the largest shares of young people received half as much Prop. K funding on a per youth basis than areas with the least concentration of youth;

- Districts with the highest rates of park accessibility received as much or more bond funds than many areas with higher poverty, higher concentrations of young people, and below average park accessibility.

These findings are of particular relevance as the City of Los Angeles decides how to allocate funds from the resent passage of two State of California bond measures (Propositions 12 and 40). In particular, they indicate that creative strategies for providing open space - such as utilizing vacant lots, alleys, underutilized school sites, public or utility-owned property, and unnecessarily wide streets - will be required in the City's older neighborhoods to redress existing inequities in access to parks. 


\section{INTRODUCTION}

Parks and open space are fundamental to the livability of cities and their neighborhoods. But in Los Angeles, a city historically conceived as a place of low-density homes each with its own private garden, civic leaders set aside extraordinarily modest amounts of land for open space and park/recreational purposes. As the city has grown and become increasingly dense, concern about lack of adequate park and recreation space for city residents has grown rapidly. The question of equity in the distribution of parks has also become particularly acute in the city's communities of color, where a shortage of park and recreation facilities is widely perceived as an environmental justice issue.

In 1996 Los Angeles voters passed the park bond measure, Proposition K, to increase and enhance park and recreation space in the city. Prop K generates $\$ 25$ million per year for acquisition, improvement, construction and maintenance of City parks and recreation facilities. Its fundamental purpose is to address the inadequacies and deterioration of the City's "youth infrastructure" - parks and recreation centers - and the currently unmet need for park, recreation, child care and community facilities. Although some projects were specified for funding in the language of the Proposition itself, much of the bond funding is allocated through a competitive process in which community-based organizations as well as city agencies and other public entities, may submit requests for funding for park improvement projects, park land acquisition, and recreational and other activity programs.

The goal of spending $\$ 25$ million yearly to improve park and open space resources in Los Angeles is laudable, but it is neither a simple nor easy task. In general, Prop K Requests for Proposals (RFPs) may be difficult for community-based organizations (CBOs) to complete, because of their length and detailed, time consuming questions. In addition, $\mathrm{CBOs}$ must have a proven track record, making it difficult for new organizations to get started in the Prop K funding system, and in some cases they must have or be able to identify additional resources to maintain facility improvements. Even if a group qualifies for consideration, their proposal still must be approved. A CBO must compete directly with the Los Angeles Recreation and Parks Department and other public agencies with extensive experience in applying for public funds.

The Prop $\mathrm{K}$ process also plays out in a city whose neighborhoods are characterized by widely divergent endowments of park and recreation resources (Map 1), as well as enormous 
socio-economic and demographic diversity. As the city developed and expanded during different eras, varying amounts of open space and parklands were set aside for public purposes, with the result that older parts of the city generally have less park and open space resources than newer areas. Population densities, household incomes, age distributions, and race/ethnicity also vary sharply in the city's various sub-areas, with the central and south-central portions of the city having the highest densities, most children and youth, and highest concentrations of people of color. In addition, environmental disamenities such as pollution and industrial land uses affect some parts of the city more than others. This variation in urban living conditions would suggest that certain areas may be in greater need of additional park and open space resources than others, although it should be noted that groups located in all areas of the city are welcome and encouraged to apply for the funds allocated to Prop K.

Now the most ethnically diverse city in the nation, Los Angeles is obligated to carefully monitor the well-being of its residents and communities of color (Map 2). For public programs, like parks and recreation, such monitoring is critical to avoid further social polarization and environmental injustice. As Prop K completes its third year of funding, it is therefore essential to assess program outcomes, in the context of existing park and open space resources in the City of Los Angeles. Which areas of the city are 'park-rich' and which are 'park-poor'? How do these patterns relate to the distribution of children and youth, especially young people of color, and to residents of low-income households? In this context, where have Prop $\mathrm{K}$ funds been allocated, and to what sorts of purposes - improvements to existing park, other sorts of recreational facilities, or new park development? Have some geographic areas been more apt to receive Prop K funding than others?

This report seeks to address these critical questions. Through a geospatial analysis of both existing and Prop K-funded park and open space resources in Los Angeles, along with an equity mapping exercise, we reveal fundamental patterns of inequality in the distribution of this vital aspect of urban livability. We also show that applicants across the city are not uniformly successful in attracting Prop K funding, and moreover, that Prop $\mathrm{K}$ funding patterns often exacerbate rather than ameliorate existing inequalities in park and open space

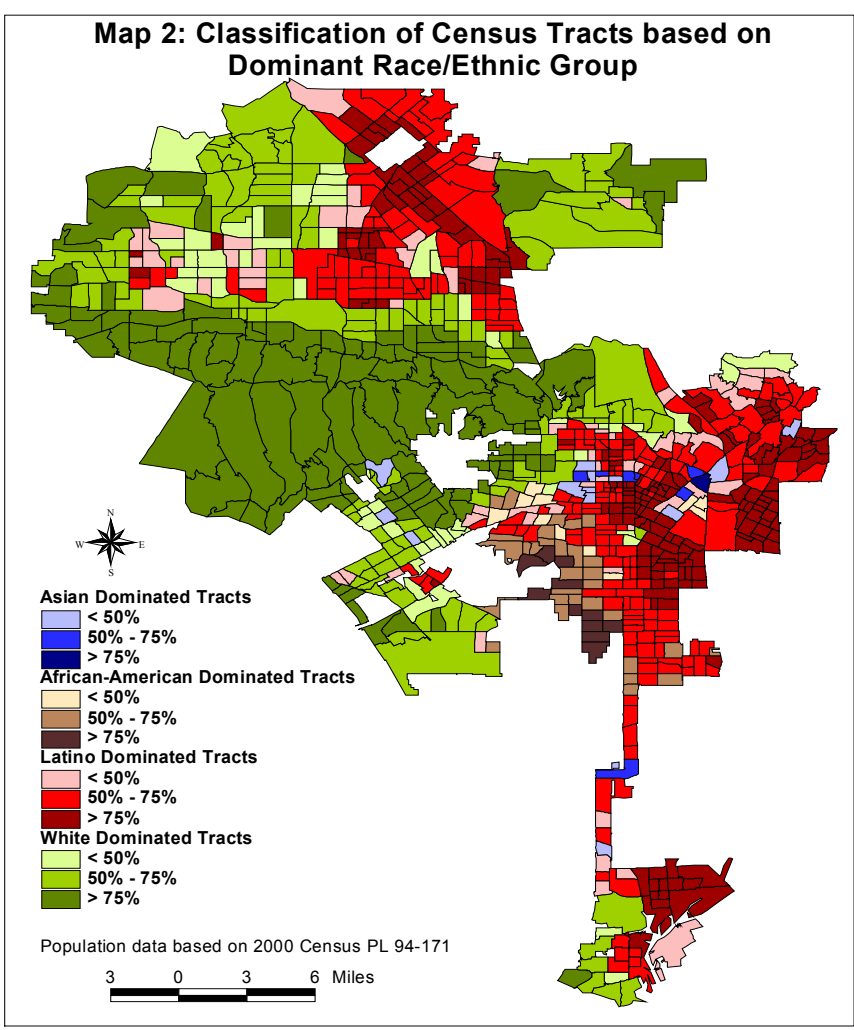
resource distributions in the City of Los Angeles. 


\section{ENVIRONMENTAL JUSTICE AND URBAN PARKS IN LOS ANGELES}

During the last decade, environmental racism - or the disproportionate exposure of people of color to environmental hazards, as well as their exclusion from benefits associated with environmental amenities - gained broad political and social attention (Albrecht, 1995), stimulating the development of a powerful social movement focused on environmental justice. As a result, since 1994, when then-President Clinton signed Executive Order 12898, all federal land management agencies were mandated to consider environmental justice in their decisionmaking (Tarrant and Cordell, 1999). Nowhere, perhaps, have issues of environmental justice been more salient than in Los Angeles.

Historically, low-income people and communities of color in the city faced not only economic discrimination and social marginalization, but also environmental racism. For example, in the early years of the $20^{\text {th }}$ Century, on the eastside of Los Angeles, industrialization prompted growth in the area (Boone and Modarres, 1998). As more factories were being built, a greater need for low wage manufacturing workers arose. While it remains unclear if the factories arose due to proximity of cheap labor or whether laborers sought homes close to new factories (Pulido et al., 1996), people of color are currently more likely to be exposed to environmental hazards in Los Angeles and face higher rates of lifetime cancer risk (Morello-Frosch et al., 2000). For instance, in 1912, the City of Torrance was developing into an industrial area. In the process of building industrial plants, an area, situated down-wind from the pollutants pouring daily from chimneys, was designated as the living area for the workers and their families, who were predominantly Latino (Pulido et al., 1996).

Because of the wider problems of social polarization, environmental justice issues related to amenities (rather then environmental hazards) have also been both a historical and modern concern. Perhaps most significant in this regard has been the question of the provision of parks and recreation. At the turn of the century, urban parks were widely deemed representations of nature that would promote a better society, by combating such social problems as poverty, crime, and poor health and providing major benefits such as better public health, social prosperity, social coherence, and democratic equality (Young, 1996). Today, many of these same reasons for building parks are offered to justify parkland acquisition and facility construction. In addition, research reveals that outdoor play is critical to younger children's social and cognitive development (Nahban and Trimble, 1994; Proshanski and Fabian, 1987; Hart, 1979), while for older children and youth park-based activities have been shown as vital alternatives to passive pastimes such as computer games and television, and to juvenile delinquency (Burgess et al., 1988).

However, in Los Angeles, low-income and minority areas have had a history of undesirable land uses, especially industrial installations with their attendant pollution of air, water, and soil. For example, the City of Los Angeles' 1904 zoning code, the first in the nation, protected the affluent, predominantly Anglo Westside from such industrial uses. Higher density housing, commercial, and industrial activities were allowed to locate by right in the city's eastern and southern areas in which lower income workers, including people of color, were concentrated 
(Weiss, 1987). Public parks, as well as other urban services were, however, disproportionately targeted to other parts of town.

Past discrimination in housing and employment, ongoing environmental racism in the siting of industrial and other polluting facilities, and inequitable distribution of urban services, mean that low income households and communities of color in Los Angeles are apt to be relegated to 'park-poor' neighborhoods, while wealthier districts are more likely to boast plentiful parks and greenbelts provided by public funding. Since more parks and greenspace translate into higher property values, this inequity translates into growing wealth disparities (Diamond, 1980; Conway et al., 2002). On an everyday basis, however, children and youth relegated to concrete sidewalks for playgrounds are arguably the greatest victims of this type of environmental injustice. This deficit in parklands is particularly problematic for older, high-density, low-income communities where children tend to utilize park resources more intensively than kids in newer, suburban areas where most housing units have gardens and there are more recreational opportunities in the environment (Loukaitou-Sideris, 1995). Thus, not surprisingly, the issue of parks and recreation is commonly cited as one of the most critical among residents of the city's low-income communities of color.

\section{FUNDING FOR LA'S URBAN PARKS AND OPEN SPACE}

At the end of World War II the park system in U.S. cities had been largely laid out and established (Young, 1996). As the population grew, so did the demand for and the price of land. This made land acquisition difficult, especially for non-tax generating land uses such as open space. With increasing suburbanization during the 1950s through 1970s, and the concomitant decline in the property tax base of most central cities, spending on parks was drastically cut, and few communities were willing to raise taxes for the park system (Garvin and Berens, 1998).

In California, Proposition 13 and ensuing tax limitations exacerbated this situation. These measures centralized fiscal resources at the state level, reduced local funding levels and flexibility, made voter approval for local tax increases far more difficult to obtain, and created incentives for sales-tax generating commercial land uses, to the detriment of housing, employment centers, and most certainly public open space (Sokolow, 1998). Thus, in the early 1980s, the City of Los Angeles was forced to close 24 recreation centers, reduce funding for the remaining 154 centers, and slash weekly operating hours of many facilities (Schwandron and Richter, 1984, as quoted in Loukaitou-Sideris and Stieglitz, 2001), and between 1972-1998 (largely the post-Prop 13 period), the City was able to purchase less than 1,000 acres for parkland, leaving the City at the bottom of the distribution in terms of parks among West Coast cities, and most of the nation's other large metropolitan areas (Harnik, 2000). In addition, the state's Quimby park funding system disproportionately advantages newer, more suburban areas of the metropolitan region. The Quimby Act requires developers to either pay in lieu funds or set aside land for park and recreation uses within, or in the immediate vicinity of, new subdivisions. Since subdivision projects are disproportionately located in outlying parts of the urban region, older, central neighborhoods receive little in the way of Quimby resources (A. Johnson Meszaros, personal communication, 2001). 
There have been several strategies in getting around the hurdle of tax increases while still supplying the growing need for more open space. One popular approach has been to turn unused government land into parks and greenbelts. In L.A., the Los Angeles River zone has been targeted for such a conversion. Extensive plans now exist to restore portions of the river to a more natural state, acquire additional adjacent parcels, and create a series of riverfront parks. Adding thousands of acres of needed open public space would benefit the many residents and property owners that live adjacent to or near the river, both financially and in terms of their well being. Indeed this strategy is being actively implemented today, due to pressure from a wide range of activist organizations, and with the aid of state park bond funding. Another strategy has been to share open space with automobiles. San Francisco was the first to utilize this strategy in 1940 when it opened a public parking garage under Union Square (Garvin and Berens, 1998). Many other cities followed suit, including Los Angeles, which created parking beneath Pershing Square in the downtown. This is not a strategy that has been widely used since, however. Lastly, public/private partnerships have become a common vehicle for park provision. In such partnerships, individual property owners, as well as business improvement districts (BID) have joined with the public sector to acquire land and manage park facilities. Under such a partnership, the public sector might donate land, while the BID might build and/or manage the park. Typically, however, these projects benefit areas that already have existing social and economic capital. A local example of such a partnership in Los Angeles is Grand Hope Park in downtown Los Angeles, which is a joint operation of a BID and the city's Community Redevelopment Agency.

\section{PROPOSITION K AND PARK FUNDING}

The City of Los Angeles, with its rapid, moderate-to-low density growth pattern, neglected to build an adequate numbers of parks and recreation facilities as its population expanded (Table 1). At about 4 acres per 1,000 residents (City of Los Angeles, 2001), provision of parklands falls far short of national standards, which range from 6.25-10.5 acres per 1,000 population (National Recreation and Parks Association, 2000). Moreover, certain neighborhoods within the city were even more neglected, leaving many children and families with no safe place to congregate and recreate. This need for more parks and recreation facilities prompted, on November 5, 1996, a majority of qualified electors within the City of Los Angeles to adopt Proposition K - also known as "The Citywide Parks, Recreation and Community Facilities Assessment Referendum Ordinance."

Table 1. Existing Parkland in the City of Los Angeles.

\begin{tabular}{lr}
\hline Total Population & $3,699,645$ \\
Total Number of Children, 0-18 years & 982,230 \\
Population Density (people per square mile) & 7,841 \\
Parkland (acres) - LA City & 15,686 \\
Parkland - LA City, as a percentage of total area & 5.2 \\
Park acres, LA City, per 1,000 people & 4.2 \\
Park acres, LA City, per 1,000 children & 16.0 \\
National Recreation \& Parks Association Standard & (acres per 1,000 population) \\
\hline
\end{tabular}


Prop K was designed to address and deal with the inadequacies of the City's children and youth infrastructure, which involves parks, community and recreation facilities, and child care - all widely seen as seriously lacking in the City of Los Angeles. Prop K generates \$25 million per year for 30 years through a real-property tax assessment. In total, Prop K allocates \$298,850,000 over its lifespan for 183 projects specified within the language of the ordinance. Another $\$ 143,650,000$ will be allocated through a competitive grant process that will fund capital improvements, maintenance, and land acquisition. To be eligible for the competitive grants process applicants must fall into one of the following three categories: (1) Government entity, (2) Community-based Organization (CBO), or (3) City Department.

In addition to Prop $\mathrm{K}$ funding, the Healthy Alternatives to Smoking Trust Fund provides funds for qualifying Census tracts in Los Angeles City (See Map 3). To qualify for the Trust Fund, the tract must have a population composed of at least 26 percent of persons under 18 years of age, at least 36 percent of youth in poverty, below average park acreage, and not be located adjacent to any major parks or national forest land.

The City of Los Angeles has designated the Commission for Children, Youth and Their Families as the agency in charge of the L.A. for Kids Program competitive grants process, which was established to distribute funding under the Prop K guidelines. The LA for Kids Program also distributes the portion of the Healthy Alternatives to Smoking Trust Fund monies allocated for parks and recreation, as part of their Prop $\mathrm{K}$ funding decisions. The Commission is responsible for the administration of the open bid process along with developing the Request for Proposals, and after receiving proposals, evaluating, rating, and giving recommendations to the LA for Kids Steering Committee and City Council. The Steering Committee and the City Council then make the final decision on the distribution of the Prop $\mathrm{K}$ funds.

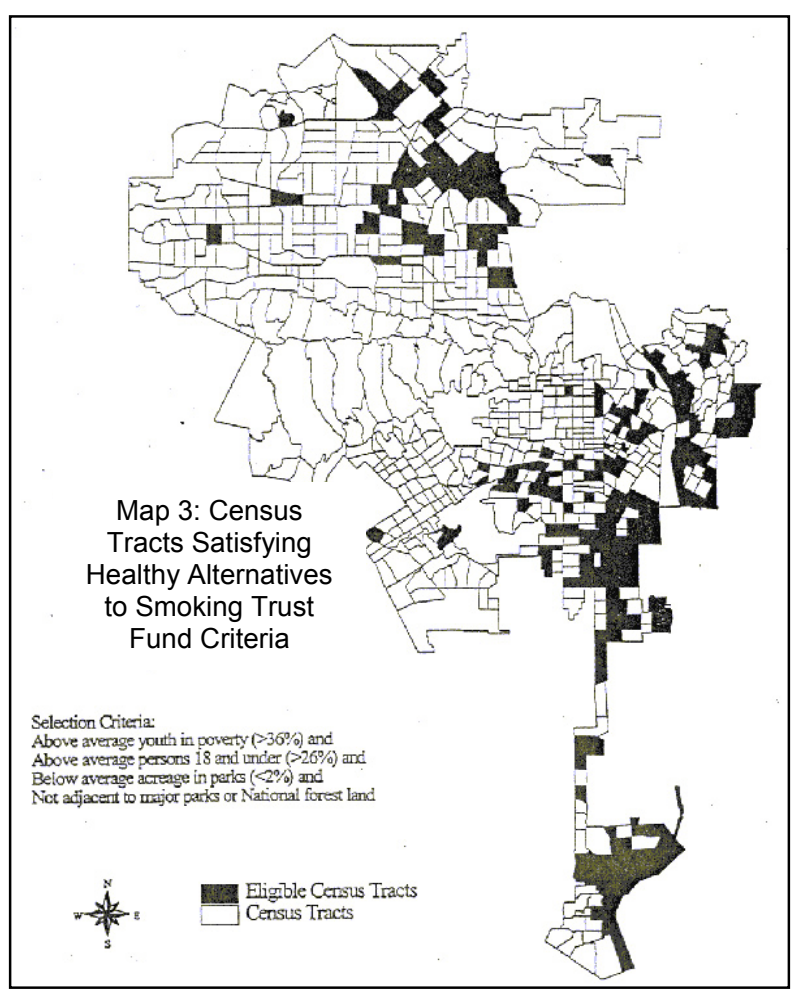

A citywide Community Needs Assessment was conducted by the Department of Recreation and Parks and the Commission for Children, Youth and Their Families to identify the categories of greatest recreational need for the city (Chart 1). They have identified eight (8) categories deemed to most need additional funding. Within the eight categories, an 'individual preferred maximum grant request' has been established to distribute the grants as assessed by the commission. 
Chart 1: Eight Major Categories of Funding under Proposition K
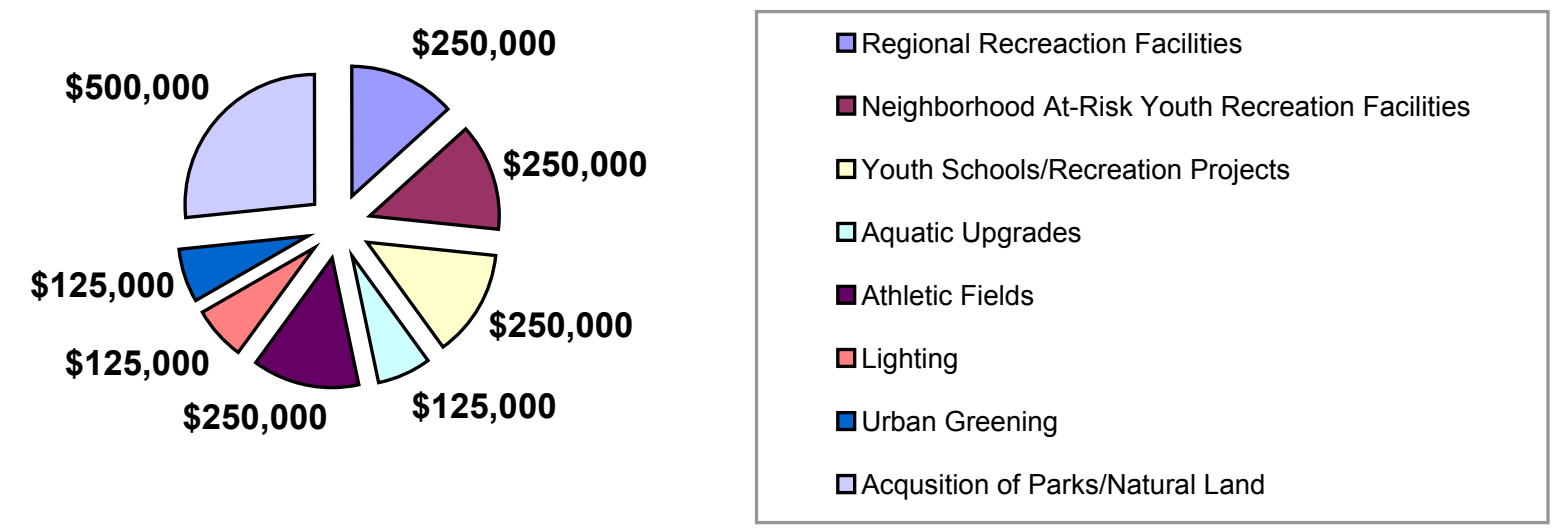

In order to keep the application process fair, the commission has set eligibility requirements for all applicants. As previously discussed, an applicant must either be a government entity, a CBO, or a City Department. In order to qualify, the proposed project must be located within the City of Los Angeles, and an applicant must show that the proposed project will bring an increase in recreation services to the City's youth population, and be accessible to the public without discrimination. Furthermore, applicants must demonstrate financial management skills and the administrative ability necessary to provide programming capital once the project is complete. Finally, the applicant must show past experience in similar projects in the Los Angeles area.

Once an applicant qualifies, their proposal receives a score based on the ability to meet five special criteria. Possible scores range from 1-100, 1 being the lowest, the maximum attainable points is 105 (100 + five bonus points). The scoring matrix is comprised of five sections pertaining to the five criteria. The first two sections, worth 25 points each, include 'demonstration of need,' and 'project design/service capability.' The 'demonstration of need' questions are based on an applicant's ability to address the concerns and needs of the target community. Project design and service capability grades the applicant on the completeness of the project design (which would include measurements of buildings, etc.) and how the initiation or expansion of the project might affect the neighborhood. The next two matrix categories, projected outcomes/evaluation and budget justification, are worth 20 points each. Project outcome/evaluation judges whether project goals are likely to produce positive outcomes. Budget justification grades the applicant on the thoroughness of the projected use of funds. The last section, worth 10 points, is based on administrative experience, which evaluates an applicant's background and reputation in managing similar projects. The five bonus points are based on how much the needs of at-risk children will be met, i.e. whether the proposed project will serve an area that has inadequate facilities or services for children and youth.

Personnel who perform the assessments are trained to score the proposals consistently, based on a sample proposal. The scores are designed to reflect the need of one proposal over another. After all the proposals have been scored, the Commission for Children, Youth and Their Families makes recommendations regarding which proposals should be funded to the LA for 
Kids Steering Committee and the City Council, for final approval. The applicants are notified by mail if they are successful in receiving a grant. There is, however, an appeals process that unsuccessful applicants can utilize.

\section{EQUITY MAPPING ANALYSIS: DATA AND METHODOLOGY}

Following Talen (1998), our analysis employed the development of a geospatial database, using information on the distribution of existing parks in the City of Los Angeles, Prop K grant applications (both accepted and rejected) by location, and census data on the demographic and socio-economic characteristics of the city's neighborhoods. These geographically coded data were then analyzed using ArcInfo and ArcView, two geographic information system (GIS) technologies, to calculate accessibility indices for various population subgroups in the city, produce associated maps, and create statistical summaries. We defined those residents living within one-quarter mile of a park edge, as having 'access' to a park. Although clearly parks differ in size, with larger parks attracting users from a broader geographic area than smaller parks, being able to walk to a park/recreation facility - of whatever size - is critical for children, youth and their families. Thus we employed a fairly conservative access indicator in our study.

In the following sections, we describe all data sources, our procedures for assessing data accuracy, and our analytic techniques.

\section{Data Sources}

Data for our analysis were derived from the following sources:

1) The US Census Bureau's 2000 geographic data set for census tract boundaries, demographic statistics, streets, city boundaries, and zip codes (http://www.esri.com/data/ online/tiger/index.html), and 1990 data on income and poverty (STF-3).

2) Center for Spatial Analysis and Remote Sensing, California State University - Los Angeles park polygon shape file (http://csars.calstatela.edu/ueicd/table.htm).

3) Government Park Webpages:

- City - http://www.laparks.org

- County - http://parks.co.la.ca.us/localparks.html

- State - http://cal-parks.ca.gov/parkindex/default.asp

- National - http://www.nps.gov/pub_aff/index.htm

4) Round 1 and 2 granted and rejected proposals from Los Angeles City Commission on Children, Youth, and Their Families.

Names and addresses were gathered from the actual approved proposals, and rejected proposals were matched with addresses from the City of Los Angeles Recreation and Parks web page, L.A. Unified School District web page, and directories of nonprofit organizations. Some could not be located; however, 98 percent of accepted proposals and 90 percent of all rejected proposals were successfully address-matched. One problematic aspect of the Prop K data on accepted and rejected proposals is that for $\mathrm{CBOs}$, the address refers to the organization rather than the project site. However, most organizations undertake projects in their immediate vicinity; thus while some error was introduced into the analysis due to this problem, it is apt to be relatively minimal. 
The existing park layer is based upon a data set maintained by the Center for Spatial Analysis and Remote Sensing, California State University, Los Angeles. Since the Center's site provides no metadata to explain the accuracy of these data, a series of crosschecks were made to assure data accuracy. In order to ground-truth the park polygon layer, we used the websites of the city, county, state, and national park agencies to confirm the existence of parks within the database. While most parks in the polygon layer were found in a second source and coded by ownership (city, county, etc.), we found that there were parks listed on the city web site that did not appear in the polygon layer. We also found that there were parks in the polygon layer that did not match any of the online lists. To solve this last problem, parks were looked up by name in a 2001 Thomas Guide for Los Angeles and Orange Counties. We found that virtually all parks in the polygon layer were listed in the Thomas Guide, confirming their existence. Eleven parks listed on the city website (http://www.laparks.org) were not found in the polygon layer, but listed in the Thomas Guide. We estimated the size of these based on an area comparison to exiting parks of similar sized parks and added them as a separate layer in the database. The approach was to try and keep the location and area of the parks as accurate as possible. However, while it was possible to estimate parks close to 1 acre, 10 acres, 50 acres, etc, such estimates are clearly subject to an error of up to 20 percent or more. As a share of total city park acreage, however, these inconsistencies caused minimal errors.

Some challenges were encountered in the course of analysis. One was the presence of sub-parks within the park system. Some larger parks have sections or adjacent parks with different names. We discovered that the parks polygon layer often summed these park acreages into a larger single park with one name, dropping the other names and boundaries. Since the location and overall park areas are accurate, this was not a major problem. Second, a small number of parks may also have been omitted because of naming convention discrepancies. Various lists provided different name formats (for example, Last_Name (First_Name), First_Name Last_Name, and Last_Name [first name dropped]). Moreover, over 20 parks in our polygon layer were simply named "Park". We were able to geospatially reference approximately half of these to parks with no specific names. Third, parks with recreation centers may have polygons that represent the area around the recreation center, not the entire park. This is the case with most of the recreation centers. Lastly, approximately 15 parks from the city website were not found in the Thomas Guide. Available information from various map sources suggests that these parks are very small and/or tied to a private institution, such as a nursing home. We chose not to include these parks in the polygon layer. Overall, the final coverage fairly represented the distribution of parklands and facilities in Los Angeles.

Ultimately, the park layer consisted of 324 parks with an overall total area of 27,068 acres (see Map 1 for geographic distribution). There are 19 parks that are less than one acre in size, 93 parks of 1-5 acres, 58 parks of 5-10 acres, 79 in the 10-25 acre range, and 75 parks of $25+$ acres. Recall that adjacent parks were often grouped into one park in the layer, and thus this size distribution may not be entirely consistent with city estimates (for example, the City reports 379 parks on its website). However, since aggregated parks functionally serve the community as one larger park this would appear to be a fair representation of the city’s park size distribution. 
It is important to note that since non-City-owned parks were included in this park layer - some of them quite large - the total park acreage considered in this analysis is almost twice that actually owned by the City: 27,068 acres versus 15,686 City-owned acres.

\section{Census Data Conversion and Creation of Park Buffers}

The Census 2000 dataset was converted for use in a DOS/Windows environment. Once properly converted, the tables were joined to provide full census tract data from the Census STF1 file, including population per tract for ethnic groups based on age. Minor manipulation was required to generate the population under the age of 18 by race/ethnic group per census tract. At this point, the data were in shapefile format, native to the ArcView 3.2 software. In addition, 1990 Census STF3 data were utilized to assess socio-economic relationships to park resources, since 2000 data on these features of the population have not yet been released.

Following the conversion, park buffers (or geographic areas) were created using the GIS, each 0.25 miles, from the edges of park polygons. These buffers represent acreage accessible to children and youth in the area adjacent to the parks. A quarter of a mile (half-mile round trip) is a reasonable distance for parents taking toddlers and small children to a park for everyday outings and playground opportunities, and given the reduction in children's independent mobility (Cunningham and Jones, 1999), trips of more than a quarter mile (especially in high-traffic areas or neighborhoods where parents have safety concerns) are unlikely to be acceptable to parents. Indeed, a national survey conducted in the 1980s indicated that only 16 percent of seven-year olds were allowed to go further than their block without adult supervision (Boocock, 1981), while a California survey done at about the same time revealed that almost 30 percent of 11-12 year olds had not make trips to local public spaces by themselves (Medrich et al., 1982).

Buffers and original park boundaries were reclassified into separate groups based on tract boundaries, creating accessible park acreage per census tract. These data were then dissolved into groups based on census tract boundaries, so that only one entity, and therefore acreage value, existed for accessible park acres per census tract. At this point, estimates of total acres within 0.25 miles of a park and total accessible population per tract, were calculated.

\section{ACCESSIBILITY OF PARKS AND RECREATION FACILITIES TO LA'S CHILDREN AND YOUTH}

Accessibility of the existing city's park and open space resources was analyzed using several measures, and for specific population and socio-economic subgroups. The population subgroups were white, black or African American, Hispanic or Latino, and Asian-Pacific Islander persons, both total population and population aged 18 or under. Economic variables considered with reference to park resources included median household income and persons in poverty. The park distribution measures used included:

1. Park acres per 1,000 population (total population and population under 18)

2. Percent of tract (or district) population (total population and population under 18) within $1 / 4$ mile of a park boundary

3. Park acres per 1,000 population (total population and population under 18) living within in $1 / 4$ mile buffer zone) 
We also used population characteristics, such as median household income or percent of persons in poverty, to characterize the socio-economic status of neighborhoods or major districts. In order to characterize the distribution of park resources and access by race/ethnic group, however, we created a set of mutually exclusive categories such that every tract is characterized by that group - white, African-American, Latino, or Asian-Pacific Islander - which claims the numerical majority of total population. Then, tracts are further distinguished according to whether their dominant group constitutes less than 50 percent, 50-75 percent, or more than 75 percent of the tract population. This system effectively highlights the location of the city's ethnic neighborhoods, revealing the concentration of whites in the western and southern San Fernando Valley, the Westside and Hollywood Hills, and Palos Verdes Peninsula; African Americans in the western side of South-Central, Latinos in South Los Angeles, Central Los Angeles, Northeast Los Angeles, the Harbor area, and parts of the Northeast Valley; and reflecting their diversity of origins, Asian-Pacific Islanders in Koreatown and the scattered tracts of Little Tokyo, Sawtelle, Little Manila, and Chinatown (Map 2).

Table 2. Division of Census Tracts by Dominant Race/Ethnic Group

\begin{tabular}{|c|c|c|c|c|c|c|c|}
\hline \multicolumn{2}{|c|}{ Dominant Group } & $\begin{array}{c}\text { Number of } \\
\text { Tracts }\end{array}$ & Whites & Latinos & Blacks & Asians & Other \\
\hline \multirow[t]{3}{*}{ Latinos } & $>75 \%$ & 188 & 39,098 & 653,745 & 35,769 & 36,998 & 4,861 \\
\hline & $50-75 \%$ & 217 & 133,440 & 636,425 & 140,301 & 98,109 & 11,185 \\
\hline & $<50 \%$ & 61 & 74,377 & 125,978 & 30,014 & 46,899 & 3,845 \\
\hline \multicolumn{2}{|c|}{ Subtotal } & 466 & 246,915 & $1,416,148$ & 206,084 & 182,006 & 19,891 \\
\hline \multirow[t]{3}{*}{ Black } & $>75 \%$ & 11 & 907 & 6,506 & 40,634 & 763 & 504 \\
\hline & $50-75 \%$ & 31 & 6,873 & 43,455 & 83,573 & 3,956 & 1,598 \\
\hline & $<50 \%$ & 11 & 5,278 & 15,333 & 19,881 & 3,982 & 743 \\
\hline \multicolumn{2}{|c|}{ Subtotal } & 53 & 13,058 & 65,294 & 144,088 & 8,701 & 2,845 \\
\hline \multirow[t]{3}{*}{ Asian } & $>75 \%$ & 1 & 90 & 843 & 112 & 4,677 & 31 \\
\hline & $50-75 \%$ & 7 & 3,984 & 7,793 & 1,957 & 18,257 & 189 \\
\hline & $<50 \%$ & 14 & 12,913 & 16,449 & 3,824 & 26,243 & 582 \\
\hline \multicolumn{2}{|c|}{ Subtotal } & 22 & 16,987 & 25,085 & 5,893 & 49,177 & 802 \\
\hline \multirow[t]{3}{*}{ White } & $>75 \%$ & 117 & 394,484 & 32,338 & 12,590 & 31,428 & 6,702 \\
\hline & $50-75 \%$ & 127 & 351,752 & 102,328 & 25,696 & 70,665 & 10,031 \\
\hline & $<50 \%$ & 53 & 111,663 & 78,525 & 17,551 & 46,420 & 4,558 \\
\hline \multicolumn{2}{|c|}{ Subtotal } & 297 & 857,899 & 213,191 & 55,837 & 148,513 & 21,231 \\
\hline \multicolumn{2}{|l|}{ Total } & 838 & $1,134,859$ & $1,719,718$ & 411,902 & $\mathbf{3 8 8 , 3 9 7}$ & 44,769 \\
\hline
\end{tabular}

Overall, we find that there are 7.3 park acres per 1,000 population, and 27.6 acres per 1,000 children. The acres per 1,000 population figure now falls within the middle of the range recommended by the National Recreation and Parks Association. However, it is vital to recall that non-City parklands were added to the parks layer since residents can utilize county, state, or federal parks - some of which are within City boundaries. Since many other communities also adjacent to parklands (such as the Santa Monica Mountains National Recreation Area) utilize these same open spaces, however, the actual parkland rates per 1,000 population would drop significantly if their populations were added into the denominator. Moreover, as detailed below, even considering county, state, and federal parklands along with City-owned lands, many 
segments of LA's population still enjoy rates far below the 6.25-10.5 range suggested by the National Recreation and Parks Association.

With regard to accessibility, we find that most residents of Los Angeles suffer from a lack of ready access to parklands. Even counting non-City owned parklands, only 29 percent of the City's population lives within a 1/4 mile of a park facility. Thus $2,639,027$ persons and 700,643 children are without easy access to park and recreation resources.

\section{Equity in the Distribution of Park Resources}

Table 2 shows the classification of census tracts by dominant race/ethnic group. These data reveal, for example, that Latinos and whites comprised the dominant groups in 56 percent and 35 percent of the census tracts, respectively. Relatively few whites (2.6 percent of total) are found in tracts dominated by African-Americans and Asian-Pacific Islanders whereas Latinos are relatively numerous throughout the City of Los Angeles (see Table 2 for details). AfricanAmericans comprised the dominant group in only 53 census tracts although substantial numbers of African-Americans (50 percent of the total African-American population) were scattered throughout the Latino-dominated tracts. Asian-Pacific Islanders were the dominant group in only 22 census tracts although relatively large numbers for these groups are scattered throughout the Latino- and white-dominated tracts (47 percent and 38 percent of total Asian-Pacific Islander population, respectively).

Table 3. Basic Park Characteristics of Neighborhoods by Dominant Race/Ethnic Group.

\begin{tabular}{|c|c|c|c|c|c|c|}
\hline \multicolumn{2}{|c|}{ Dominant Group } & \multirow{2}{*}{$\begin{array}{c}\begin{array}{c}\text { Total } \\
\text { Population }\end{array} \\
477,482\end{array}$} & \multirow{2}{*}{$\begin{array}{c}\begin{array}{c}\text { Population } \\
\text { Density } \\
\text { (persons/ } \\
\text { sq. mi.) }\end{array} \\
5.1\end{array}$} & \multirow{2}{*}{$\begin{array}{c}\begin{array}{c}\text { Children } \\
\text { Under 18 }\end{array} \\
16.5 \%\end{array}$} & \multirow{2}{*}{$\begin{array}{c}\begin{array}{c}\text { Park Acres } \\
\text { per 1,000 } \\
\text { Population }\end{array} \\
31.8\end{array}$} & \multirow{2}{*}{$\begin{array}{c}\begin{array}{c}\text { Park Acres } \\
\text { per 1,000 } \\
\text { Children }\end{array} \\
192.9\end{array}$} \\
\hline White & $>75 \%$ & & & & & \\
\hline & $50-75 \%$ & 560,472 & 8.2 & $18.6 \%$ & 12.2 & 65.7 \\
\hline & $<50 \%$ & 258,717 & 13.9 & $20.4 \%$ & 2.1 & 10.1 \\
\hline Total & & 1,296,671 & 7.2 & $18.2 \%$ & 17.4 & 95.7 \\
\hline \multirow[t]{3}{*}{ Latino } & $>75 \%$ & 770,471 & 24.0 & $34.7 \%$ & 0.6 & 1.6 \\
\hline & $50-75 \%$ & $1,019,460$ & 18.4 & $31.8 \%$ & 2.6 & 8.2 \\
\hline & $<50 \%$ & 281,113 & 15.7 & $25.3 \%$ & 0.9 & 3.7 \\
\hline Total & & $2,071,044$ & 19.7 & $32.0 \%$ & 1.6 & 5.0 \\
\hline African- & $>75 \%$ & 49,314 & 16.0 & $26.8 \%$ & 1.7 & 6.3 \\
\hline \multirow[t]{2}{*}{ American } & $50-75 \%$ & 139,455 & 20.1 & $30.2 \%$ & 0.7 & 2.4 \\
\hline & $<50 \%$ & 45,217 & 21.6 & $21.5 \%$ & 0.1 & 0.4 \\
\hline Total & & 233,986 & 19.3 & $27.8 \%$ & 0.8 & 2.9 \\
\hline Asian- & $>75 \%$ & 5753 & 23.0 & $17.7 \%$ & 0.3 & 1.9 \\
\hline Pacific & $50-75 \%$ & 32,180 & 25.0 & $19.7 \%$ & 0.6 & 3.3 \\
\hline Islander & $<50 \%$ & 60,011 & 20.8 & $18.8 \%$ & 1.6 & 8.4 \\
\hline Total & & 97,944 & 22.1 & $19.0 \%$ & 1.2 & 6.3 \\
\hline
\end{tabular}

The distribution of park resources is also highly uneven across race/ethnic neighborhoods of the city. As shown in Table 3, Latino and Asian-Pacific Islander neighborhoods have the highest population densities, followed closely by African Americans; densities in all three types of neighborhoods are up to almost two to five times higher than in white-dominant neighborhoods. Latino areas, with two-thirds of a million children, have almost three times as many children, 
living at five times the density as residents in heavily white areas. Yet those areas with 75 percent or more Latino population (188 tracts, with over 770,000 residents) have only 0.6 park acres per 1,000 population, and heavily African American dominated tracts (11 tracts with almost 50,000 residents) have 1.7 park acres per 1,000 population. In comparison, heavily white dominated areas (117 tracts with almost 480,000 residents) enjoy 31.8 park acres per 1,000 residents.

\section{Accessibility and the Latino Population}

Over 2 million people, including more than 660,000 children, reside in tracts in which the numerically dominant population is Latino. Overall, residents of Latino neighborhoods on average enjoy only 1.6 acres per 1,000 population, and 5 acres per 1,000 child under 18 (Table 3). As shown in Table 4, less than a third of the population lives within a $1 / 4$ mile of parkland in these neighborhoods. Almost 500,000 children - 73 percent - have no easy access to park facilities. The areas with the highest shares of Latino residents are the worst-off in terms of park acres per 1,000 residents and children living within a 1/4 mile from a park. In comparison, those tracts with moderately high shares have more park resources.

Table 4. Latino Population Accessibility to Parks.

\begin{tabular}{lcccc}
\hline Percent Latino & $\begin{array}{c}\text { Population within } \\
\text { 1/4 Mile Buffer }\end{array}$ & $\begin{array}{c}\text { Number of } \\
\text { Children outside } \\
\text { 1/4 Mile Buffer }\end{array}$ & $\begin{array}{c}\text { Park Acres/1,000 } \\
\text { Population within 1/4 } \\
\text { Mile Buffer }\end{array}$ & $\begin{array}{c}\text { Park Acres/1,000 } \\
\text { Under 18 within 1/4 } \\
\text { Mile Buffer }\end{array}$ \\
\hline$>75 \%$ & $29.9 \%$ & 190,894 & 1.9 & 5.5 \\
$50-75 \%$ & $28.5 \%$ & 235,154 & 9.5 & 29.9 \\
$<50 \%$ & $20.4 \%$ & 56,173 & 4.8 & 18.9 \\
Totals & $26.7 \%$ & 482,221 & 6.0 & 18.4 \\
\hline
\end{tabular}

The most heavily Latino areas of Los Angeles are primarily in South Los Angles, Central Los Angeles, Northeast Los Angeles, the Harbor area, and parts of the Northeast Valley. These are some of the highest population density areas in the City. In South, Central, and Northeast Los Angeles, there are several parks in the middle of the largely-Latino census tracts, but population densities are extremely high, thus lowering per capita estimates. Parks are also limited in tracts with the highest concentrations of Latinos in the Northeast Valley (specifically Sun Valley, Arleta-Pacoima, and Sylmar) and South Los Angeles (Map 4).

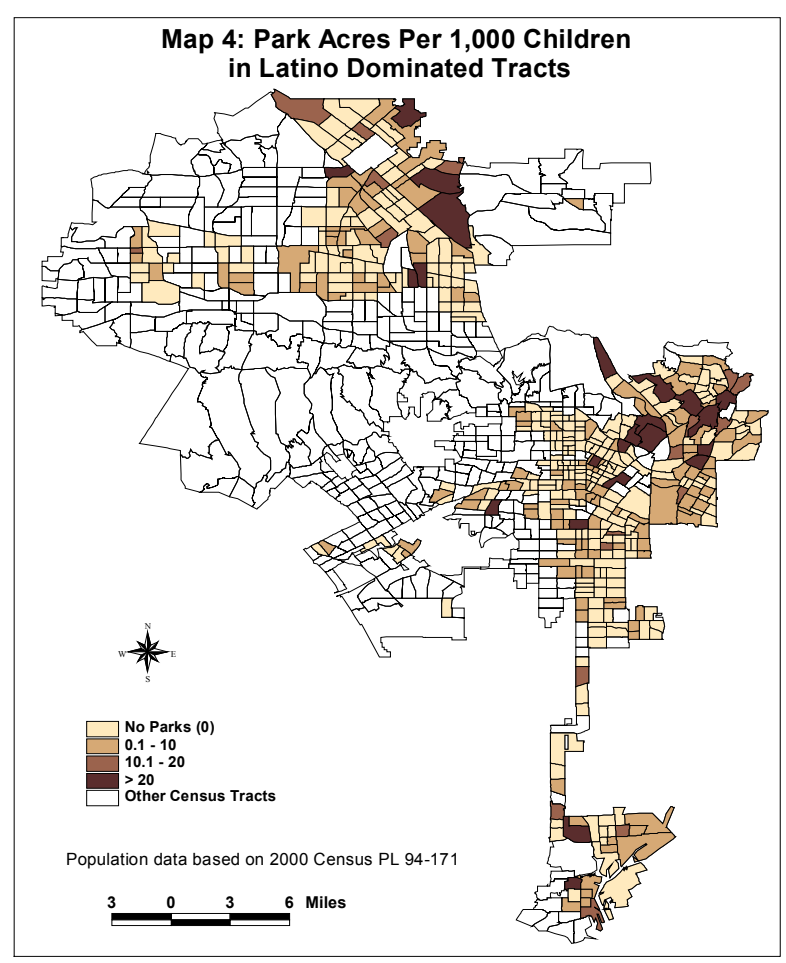




\section{African American Accessibility to Parks}

Over 230,000 people, including over 65,068 children under 18 , reside in tracts in which the numerically dominant population is African American. In these neighborhoods, less than a third of the population lives within a $1 / 4$ mile of parkland, and almost 50,000 children - 74 percent - have no easy access to park facilities (Table 5). Combining all information on African American dominated tracts, residents of African American neighborhoods on average have only 0.8 acres per 1,000 population; children in their districts have only 2.9 acres per 1,000 - the lowest in the City (Table 3 ).

African American dominated neighborhoods tend to be heavily concentrated in South Central Los Angeles, South East Los Angeles, the Harbor Gateway, the West Adams Baldwin Hills - Leimert Park area, and

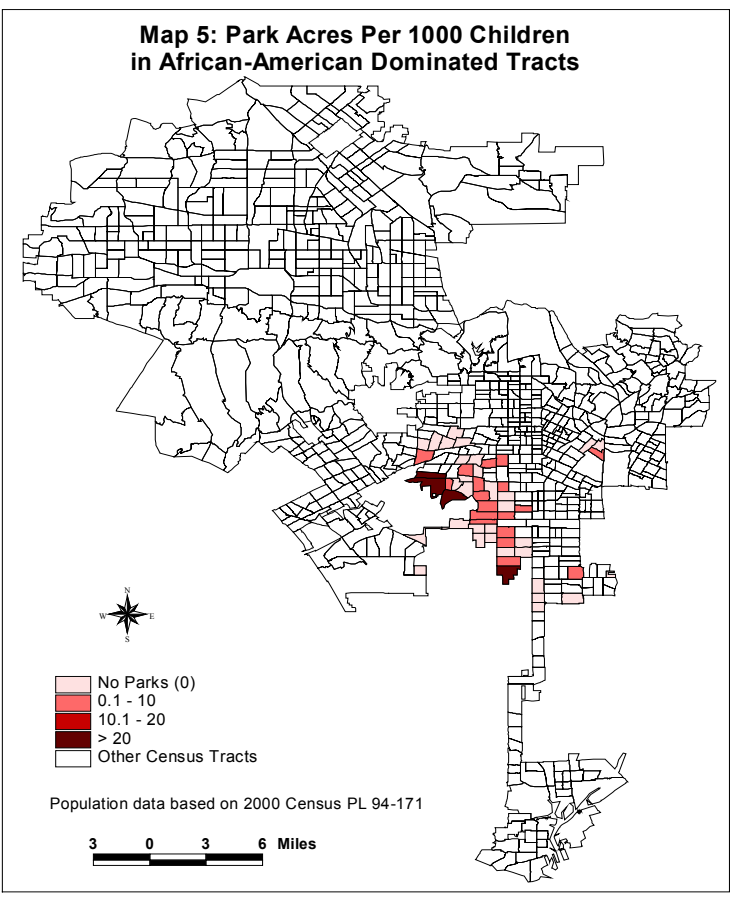
Wilshire. In most other parts of the city, representation of African Americans is very low, i.e. 8 percent or less. Throughout areas with the highest shares of African Americans, there are several large parks (such as Hahn Park in the Baldwin Hills and Magic Johnson Park). However, in most African American dominated areas, the number of park acres per 1,000 children is low (Map 5).

Table 5. African American Accessibility to Parks.

\begin{tabular}{lcccc}
\hline $\begin{array}{l}\text { Percent African } \\
\text { American }\end{array}$ & $\begin{array}{c}\text { Population within } \\
\text { 1/4 Mile Buffer }\end{array}$ & $\begin{array}{c}\text { Number of } \\
\text { Children outside } \\
\text { 1/4 Mile Buffer }\end{array}$ & $\begin{array}{c}\text { Park Acres/1,000 } \\
\text { Population within 1/4 } \\
\text { Mile Buffer }\end{array}$ & $\begin{array}{c}\text { Park Acres/1,000 } \\
\text { Under 18 within 1/4 } \\
\text { Mile Buffer }\end{array}$ \\
\hline$>75 \%$ & $33.5 \%$ & 8,849 & 5.0 & 19.2 \\
$50-75 \%$ & $22.3 \%$ & 31,859 & 3.0 & 10.0 \\
$<50 \%$ & $22.6 \%$ & 7,640 & 0.4 & 1.9 \\
Total & $26.2 \%$ & 48,348 & 3.1 & 11.4 \\
\hline
\end{tabular}

\section{Asian-Pacific Islander Access to Parks}

Park access in areas of Asian-Pacific Islander concentration varies greatly. Almost 100,000 people live in these neighborhoods, about 18,600 of whom are under 18. In these districts, les than 30 percent of the population lives within a 1/4 mile of parkland, leaving 13,000 children without ready access to park facilities (Table 6). Combining all Asian-Pacific Islander-dominated tract information, residents of these neighborhoods on average have only 1.2 acres per 1,000 residents, while children in these districts have 6.3 acres per 1,000 (Table 3). 


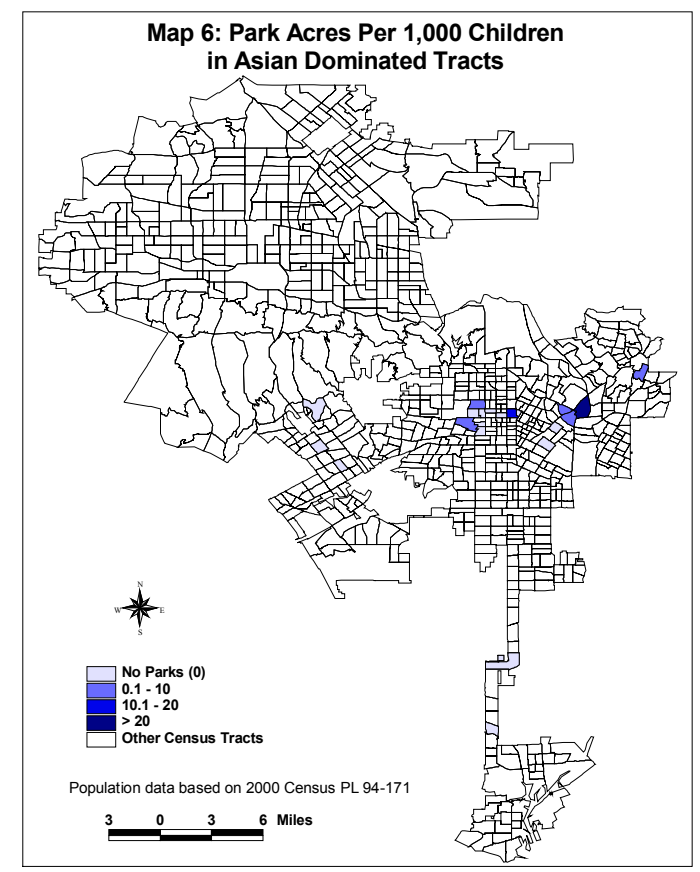

There are relatively few neighborhoods that are heavily dominated by this population subgroup. The Asian-Pacific Islander dominated areas in the Metro Center and Northeast Los Angeles area (Hollywood, Wilshire, Silver Lake - Echo Park, Northeast Los Angeles), Koreatown, and in small patches of South Los Angeles. Park acres per 1,000 children is uneven in these areas - relatively high near Elysian Park, for example, but fairly low in Central LA areas (Map 6).

Table 6. Asian-Pacific Islander Access to Parks.

\begin{tabular}{lcccc}
\hline $\begin{array}{l}\text { Percent Asian } \\
\text { Pacific Islander }\end{array}$ & $\begin{array}{c}\text { Population within } \\
\text { 1/4 Mile Buffer }\end{array}$ & $\begin{array}{c}\text { Number of } \\
\text { Children outside } \\
\text { 1/4 Mile Buffer }\end{array}$ & $\begin{array}{c}\text { Park Acres/1,000 } \\
\text { Population within 1/4 } \\
\text { Mile Buffer }\end{array}$ & $\begin{array}{c}\text { Park Acres/1,000 } \\
\text { Under 18 within 1/4 } \\
\text { Mile Buffer }\end{array}$ \\
\hline$>75 \%$ & $46.2 \%$ & 547 & 0.7 & 4.0 \\
$50-75 \%$ & $37.1 \%$ & 3,648 & 1.6 & 7.7 \\
$<50 \%$ & $16.0 \%$ & 8,965 & 9.3 & 41.0 \\
Total & $26.0 \%$ & 13,160 & 4.6 & 21.4 \\
\hline
\end{tabular}

\section{White Population and Park Access}

Park acres per 1,000 white population (total and children) is dramatically higher than for other groups, particularly in the most heavily white areas. On average, white dominated neighborhoods enjoy 17.4 acres per 1,000 residents, and 95.7 acres per 1,000 children (Table 3 ). In part this is due to the fact that white-dominated areas encompass the Santa Monica Mountains. Similarly, park acres per 1,000 population (total and under 18) within a quarter mile of a park, are dramatically higher than for other groups (Table 7).

Table 7. White Access to Parks.

\begin{tabular}{lcccc}
\hline Percent White & $\begin{array}{c}\text { Population within } \\
\text { 1/4 Mile Buffer }\end{array}$ & $\begin{array}{c}\text { Number of } \\
\text { Children outside } \\
\text { 1/4 Mile Buffer }\end{array}$ & $\begin{array}{c}\text { Park Acres/1,000 } \\
\text { Population within 1/4 } \\
\text { Mile Buffer }\end{array}$ & $\begin{array}{c}\text { Park Acres/1,000 } \\
\text { Under 18 within 1/4 } \\
\text { Mile Buffer }\end{array}$ \\
\hline$>75 \%$ & $21.8 \%$ & 59,799 & 140.7 & 800.8 \\
$50-75 \%$ & $22.0 \%$ & 81,610 & 54.4 & 300.9 \\
$<50 \%$ & $21.6 \%$ & 41,559 & 9.6 & 47.4 \\
Total & $22.3 \%$ & 182,968 & 78.2 & 426.2 \\
\hline
\end{tabular}


In areas with less than 50 percent white population, which are located away from the mountains, the park acres measures are far more modest; yet they are still far higher than for all but three of the nine other groups. Nevertheless only just over a fifth of the population in white dominated neighborhoods has easy access to parklands.

This apparent contradiction is explained, once again, by the role and location of the Santa Monica Mountains, which are relatively far from most white neighborhoods, and the fact that many white-dominated areas are lower density, making distances to parks greater in general in these parts of the City. The pattern is similar when considering park acres in relation to the distribution of children in white dominated tracts (Map 7). Children living in central Valley neighborhoods, as well as those in parts of West Los Angeles, have relatively poor access to parks, in contrast to those living near the city's large open spaces.

\section{Park Access and Socioeconomic Status}

Lower income households have much worse access to park resources than the higher income. Over 230,000 children lived in the 150 tracts in which 1990 household income

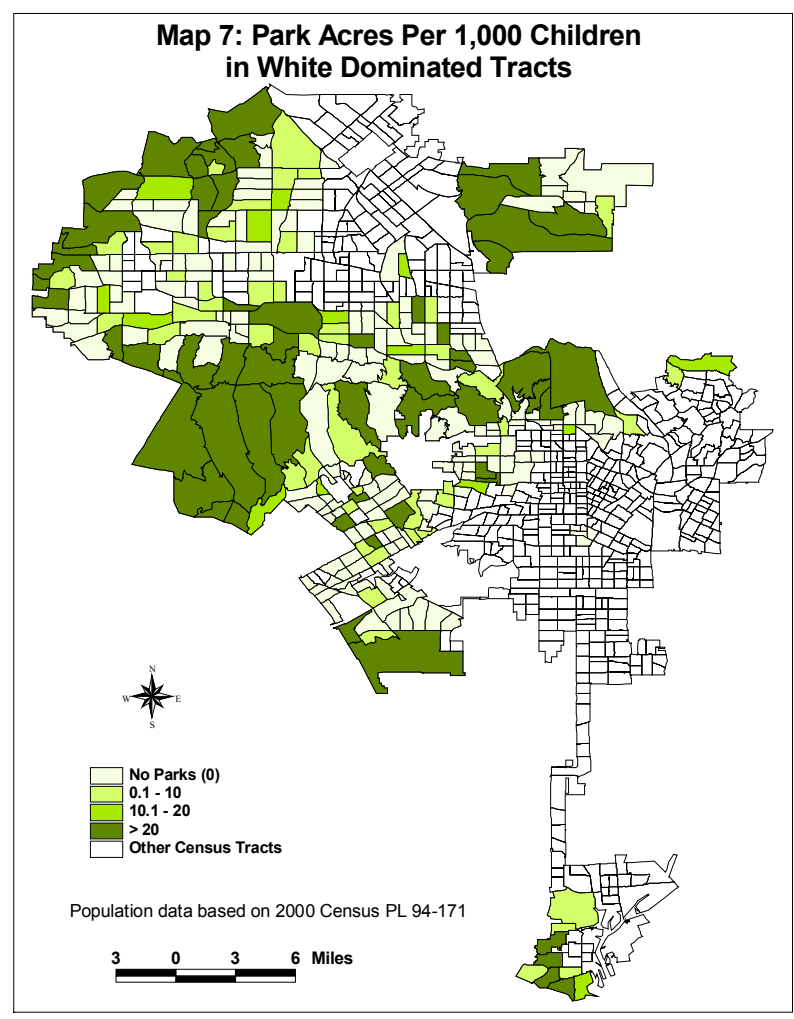
fell below $\$ 20,000$ per year. Only 30 percent of children had easy access to parks, leaving 160,000 kids without such access (Table 8). On average, residents in such low-income neighborhoods enjoyed less than $1 / 2$ park acre per 1,000 total population (1.6 park acres per 1,000 children), and 1.6 acres per 1,000 living within easy access. In contrast, neighborhoods where 1990 household incomes were $\$ 40,000$ or higher, housing approximately 890,000 residents, boasted 21.2 park acres per 1,000 total population (109 park acres per 1,000 children). The share of children without 1/4 mile access was lower, however, due to the fact that many such households lived in lower density areas (especially near the Santa Monica Mountains) where neighborhood services of all types are more spread out.

Similarly, areas with high poverty concentration had much worse access than tracts with a low incidence of poverty. Neighborhoods in which 40 percent or more of residents were below the federal poverty line in 1990, with about 200,000 residents total, had about 1 acre of parkland per 1,000 residents ( 3 park acres per 1,000 kids), whereas areas with negligible poverty had about 19 acres per 1,000 dwellers (100 park acres per 1,000 kids). Access was dramatically worse in the high poverty areas; almost 300,000 young people in tracts with 20 percent or more in poverty had no easy access to parks. 
Table 8. Socioeconomic Status and Access to Parks.

\begin{tabular}{llccccc}
\hline & & $\begin{array}{c}\text { Population } \\
\text { within } 1 / 4 \\
\text { Mile } \\
\text { Buffer }\end{array}$ & $\begin{array}{c}\text { Number of } \\
\text { Children } \\
\text { outside 1/4 Mile } \\
\text { Buffer }\end{array}$ & $\begin{array}{c}\text { Park } \\
\text { Acres/1000 } \\
\text { Population }\end{array}$ & $\begin{array}{c}\text { Park Acres/1,000 } \\
\text { Population within } \\
1 / 4 \text { Mile Buffer }\end{array}$ & $\begin{array}{c}\text { Park } \\
\text { Acres/1,000 } \\
\text { Under 18 within } \\
1 / 4 \text { Mile Buffer }\end{array}$ \\
\hline $\mathbf{1 9 9 0}$ & $>\$ 40,000$ & $20.8 \%$ & 136,595 & 21.2 & 102.9 & 517.0 \\
Median & $\$ 30-40,000$ & $20.4 \%$ & 146,679 & 5.9 & 28.1 & 129.6 \\
Household & $\$ 20-30,000$ & $27.7 \%$ & 195,991 & 1.4 & 5.0 & 17.7 \\
Income & $<\$ 20,000$ & $29.9 \%$ & 160,353 & 0.5 & 1.6 & 5.2 \\
\hline \multirow{2}{*}{ 1990 } & $<10 \%$ & $21.4 \%$ & 172,753 & 18.9 & 86.8 & 451.5 \\
Percent & $10.1-20 \%$ & $20.6 \%$ & 175,293 & 1.9 & 9.2 & 39.1 \\
in Poverty & $20.1-40 \%$ & $29.2 \%$ & 250,772 & 1.2 & 3.9 & 12.8 \\
& $>40 \%$ & $36.5 \%$ & 40,802 & 1.0 & 2.8 & 7.7 \\
\hline Total & & $24.8 \%$ & 639,618 & 7.3 & 29.6 & 113.1 \\
\hline
\end{tabular}

\section{Summary Assessment}

In summary, we find striking inequities in the distribution of park space for children/youth of Los Angeles. Considering park acres per 1,000 residents, it is clear that low income and concentrated poverty areas have relatively low levels of park resources and access. Moreover, African American, Asian-Pacific Islander, and Latino dominated neighborhoods, where almost 750,000 children live, have extraordinarily low rates (1-2 acres per 1,000 total population, and 3-6 acres per 1,000 children) compared to white dominated areas (with almost 17 and 100 acres per 1,000 total population and children, respectively) where only 235,000 children reside.

In those neighborhoods that are almost exclusively Latino, the number of total park acres, and accessible park acres per 1,000 , are shockingly low: less that an acre per 1,000 population in park acreage, and less than 2 acres per 1,000 population living within a quarter mile of existing parks. This compares to 32 acres and 141 acres per 1,000 residents within a quarter mile of a park in those neighborhoods in which 75 percent or more of the population is white. Residents of Asian-Pacific Islander dominated areas have the highest probability of living within easy access to a park facility (30 percent) compared to probabilities in the 20-30 percent range for other groups. But the vast majority of residents, including children, in each of the four types of race/ethnic neighborhoods areas have poor access to parklands. In white dominated areas this is in part due to low density, while in other areas few park resources combines with high density to produce a double-whammy: poor access, and extraordinarily low park acres per person/child.

\section{DISTRIBUTION OF PROPOSITION K RESOURCES}

Prop. K funds have been distributed in two cycles, with the first starting in 1998 and the second starting in 1999 and ending in 2000. During this period, based on data obtained from the Commission on Children, Youth and their Families, we estimate that $\$ 38,572,059$ was granted to qualified applicants. These grant data include funds allocated, and funds planned to be allocated by the Commission, to projects through Proposition $\mathrm{K}$ (including those allocated from the Healthy Alternatives to Smoking Trust Fund dollars). It should be noted that the Commission data sources were not uniformly consistent; funding amounts reported here should be considered estimates. The grants were awarded by category, depending on the type of project to be completed (Chart 2). 


\section{Chart 2: Percent of Total Awards by Category (1st and 2nd Rounds)}

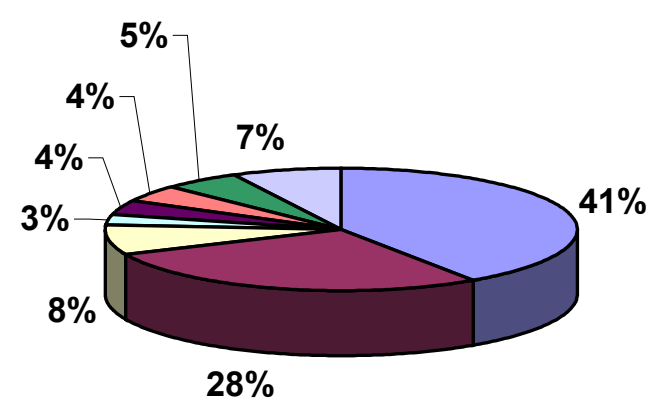

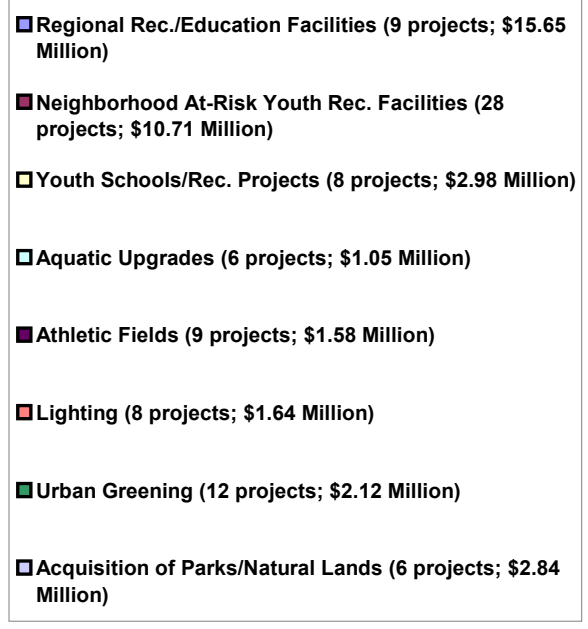

In category 1 (regional facilities), 9 applicants were funded, and share the greatest dollar amount of any category. The Commission decided that the high cost of capital improvements at regional recreation/educational facilities justified the higher expenditures. Category 2 projects (neighborhood at-risk youth facilities) obtained the second largest share of funding, with 28 recipients receiving almost $\$ 11$ million. This category resembles category 1 but creates capital improvements at neighborhood facilities for at-risk youth, and is more open to a range of facilities eligible to receive a grant. Many elementary and senior high schools vied for funds from category 3 , youth schools/recreation projects. Category 4 (aquatic upgrades) ranged from new pool facilities to water slides, and expanding pool facilities in the City, all provided by just over $\$ 1$ million to aquatic improvements. Category 5 is reserved for improvements to athletic fields, for instance new sod for baseball diamonds or the resurfacing of tennis courts. The next category (6), for lighting, is related to the previous category because applicants can apply for the lighting of athletic fields. Urban Greening (category 7) provides funds for planting grass and other foliage, trees and community gardens, and for graffiti prevention. The urban greening category received the second highest number of applicants, but allocated far less dollars than several other categories. Applicants accepted for allocations from category 8 resources had to acquire parks/natural lands for park purposes. Since the City had to own any land acquired, this greatly limited the number and type of applicants under this category.

Three funded projects, as well as 17 rejected projects, could not be geocoded and were dropped from analysis. We furthermore eliminated seven funded projects that used the Los Angeles Department of Recreation and Parks as the project address, as well as the Los Angeles Children's museum (\$9.5 million), which was a large regional project. Thus in our geographical analyses, we considered \$25,408,739 in Prop K grants spread over 181 grant proposals (of which 76 were accepted). 


\section{Proposition K Applicants and Existing Accessible Park Space}

Map 8 shows existing accessible park space within Los Angeles along with the site locations of both accepted and rejected Prop K applications. A large majority of the accepted applicants are within or adjacent to accessible park spaces, as opposed to being associated with school sites or other government facilities, or CBO sites. Most CBO applications were in partnership with an existing park/recreation facility; in some cases, such as the TreePeople application for funds to plant trees throughout the San Fernando Valley, the application is geographically coded as the CBO's office location. It must also be noted that the Prop K database refers not to the site of the project but the address of the applicant CBO. But while in some instances CBOs may undertake projects at a large distance from their organizational base, in most cases proposed projects are apt to be located in nearby neighborhoods.

Both accepted and rejected applications are widespread throughout the city. The two San Fernando Valley subregions have a geographically dispersed distribution, with no identifiable pattern; many subareas of the Valley had few Prop K proposals either submitted or funded, and also lacked much existing accessible park space. The majority of the accepted applicants are within or adjacent to accessible park spaces in the Valley. Downtown-Hollywood, East, and South-central Los Angeles had the most total applicants (accepted and rejected). Many of the accepted

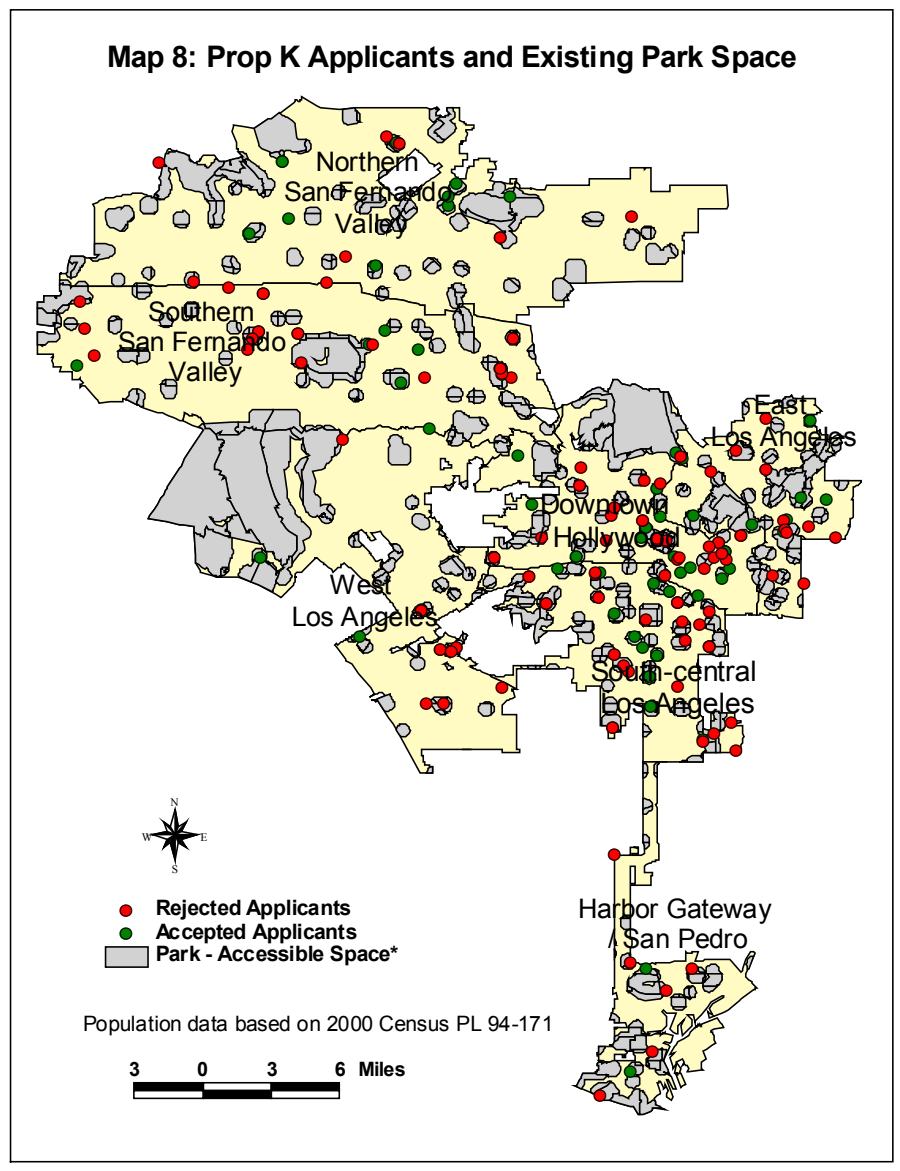
proposals are within the $1 / 4$ mile radius of existing parks, in areas of high population density where need for park space is acute. In the Harbor Gateway/San Pedro district there were far fewer applicants and both the accepted and rejected proposals tended to fall within the $1 / 4$ mile buffer area surrounding park boundaries, since most applications were for improvements of existing parks. West LA had few accepted proposals.

\section{Proposition K Funding and the Child/Youth Population}

Our analysis suggests that much of the $\$ 25$ million a year the measure generates was not allocated to areas where it is most needed, during the 1998-2000 period. Although Prop K funds were disproportionately allocated - in absolute and per capita terms - to areas with a larger share of youthful residents, allocations would have had to be even more targeted to such 
neighborhoods to achieve equity on a per child basis. Citywide, $\$ 25.87$ in Prop $\mathrm{K}$ funds was spent per person under 18 , and $\$ 6.87$ per capita. Areas with the least share of children and youth got the most funding on a per youth basis but least on a per capita basis. In areas with the highest concentrations of young people, expenditures per young person were 15 percent lower than the city average. However, these same tracts received 18 percent more money per capita (including adults and children) than the city average (Table 9). Those census tracts where less than a fifth of total population was under 18 received twice as much on a per youth basis than did those areas with the greatest share of youngsters (in which between a third to more than half of the population was under age 18). And areas with higher concentrations of youth population had lower funding proposal success rates than areas with lower concentrations of young people. Nevertheless, tracts with the highest percentage youth residents did receive the most money in absolute terms, per adult, and per capita.

Table 9. Prop K Funding by Percent Population Under 18.

\begin{tabular}{lccccc}
\hline $\begin{array}{l}\text { Population Under 18 } \\
\text { (quartiles) }\end{array}$ & Total Population & Total Children & $\begin{array}{c}\text { Proposal } \\
\text { Success } \\
\text { Rate }\end{array}$ & $\begin{array}{c}\text { Per Child } \\
\text { Spending }\end{array}$ & $\begin{array}{c}\text { Total Prop K } \\
\text { Spending }\end{array}$ \\
\hline $0-20.8 \%$ & 899,816 & 127,498 & $48 \%$ & $\$ 42.63$ & $\$ 5,435,635$ \\
$20.9-27.5 \%$ & 952,088 & 231,707 & $50 \%$ & $\$ 26.90$ & $\$ 6,233,378$ \\
$27.6-33.1 \%$ & 931,159 & 283,631 & $35 \%$ & $\$ 22.18$ & $\$ 6,291,948$ \\
$33.2-57.8 \%$ & 916,582 & 339,394 & $42 \%$ & $\$ 21.94$ & $\$ 7,447,778$ \\
Total & $3,699,645$ & 982,230 & $44 \%$ & $\$ 25.87$ & $\$ 25,408,739$ \\
\hline
\end{tabular}

\section{Proposition K Applications and Socioeconomic Status}

Prop $\mathrm{K}$ funds do appear to be targeted toward lower income and poorer neighborhoods of the City. However, on a per child basis, spending is more evenly spread across poorer and more affluent areas (Table 10). Note that income and poverty data are derived from the 1990 census; hence spending rate figures cannot be directly compared with those presented above in Table 9, or below in Table 11.

Low-income neighborhoods generated more Prop $\mathrm{K}$ proposals than more affluent areas, in absolute numbers and proposals per 100,000, and enjoyed a higher success rate. Per capita spending was almost double that of the most affluent tracts. But the difference in funding per child was much smaller.

Neighborhoods with high rates of poverty also received more Prop K funds on a per capita (almost four times as high in the highest poverty tracts than in the lowest), and per child basis (with high poverty tracts attracting over twice the per child dollars than the lowest poverty areas). Success rates were higher in high-poverty areas as well. There were, however, only 42 tracts in the high poverty category (with about 200,000 residents); rates of spending per child in those areas with 20-40 percent in poverty (with almost 1.2 million residents) were somewhat higher than low poverty areas with about the same total population - but not by much (only $\$ 4.01$ or 16 percent on a per child basis). 
Table 10. Prop K Funding by Socioeconomic Status.

\begin{tabular}{|c|c|c|c|c|c|c|c|c|}
\hline & & \# Tracts & $\begin{array}{l}1990 \text { Total } \\
\text { Population }\end{array}$ & $\begin{array}{l}1990 \text { Total } \\
\text { Children }\end{array}$ & $\begin{array}{c}\text { Proposal } \\
\text { Success } \\
\text { Rate }\end{array}$ & $\begin{array}{l}\text { Per Capita } \\
\text { Prop K } \\
\text { Spending }\end{array}$ & $\begin{array}{l}\text { Per Child } \\
\text { Prop K } \\
\text { Spending } \\
\end{array}$ & $\begin{array}{c}\text { Total Prop K } \\
\text { Funding }\end{array}$ \\
\hline \multirow{3}{*}{\multicolumn{2}{|c|}{$\begin{array}{ll}1990 & <\$ 20,000 \\
\text { Median } & \$ 20-30,000 \\
\text { Household } \$ 30-40,000\end{array}$}} & 150 & 771,558 & 233,837 & $48 \%$ & $\$ 9.96$ & $\$ 32.85$ & $\$ 7,680,996$ \\
\hline & & 179 & 990,371 & 274,311 & $46 \%$ & $\$ 8.87$ & $\$ 32.01$ & $\$ 8,781,737$ \\
\hline & & 169 & 848,064 & 185,538 & $46 \%$ & $\$ 5.23$ & $\$ 23.90$ & $\$ 4,433,833$ \\
\hline Income & $\$>40,000$ & 222 & 892,559 & 173,138 & $32 \%$ & $\$ 5.06$ & $\$ 26.06$ & $\$ 4,512,173$ \\
\hline \multirow{5}{*}{$\begin{array}{l}1990 \\
\text { Percent in } \\
\text { Poverty }\end{array}$} & $>40 \%$ & 42 & 202,427 & 66,098 & $48 \%$ & $\$ 16.75$ & $\$ 51.28$ & $\$ 3,389,695$ \\
\hline & $20.1-40 \%$ & 207 & $1,184,367$ & 358,699 & $43 \%$ & $\$ 8.66$ & $\$ 28.59$ & $\$ 10,255,172$ \\
\hline & $10.1-20 \%$ & 182 & 929,138 & 219,719 & $48 \%$ & $\$ 6.78$ & $\$ 28.68$ & $\$ 6,300,740$ \\
\hline & $<10 \%$ & 289 & $1,186,620$ & 222,308 & $41 \%$ & $\$ 4.60$ & $\$ 24.58$ & $\$ 5,463,132$ \\
\hline & Total & 720 & $3,502,552$ & 866,824 & $44 \%$ & $\$ 7.25$ & $\$ 29.31$ & $\$ 25,408,739$ \\
\hline
\end{tabular}

\section{Proposition K Applications and Race/Ethnicity}

The generation of Prop K proposals, their success rates, and funding awards, were analyzed by race/ethnic population distribution, utilizing the categorization of tracts according to the extent of domination by a particular race/ethnic group. Again, it should be noted that several proposals, totaling \$11.76 million and all generated technically within Latino-dominated areas, were removed from the analysis; these proposals had no address associated with them other that that of the City's Department of Recreation and Parks City Hall office, although the funds were clearly not destined to be spent in downtown. In addition, this total includes the Los Angeles Children's Museum application - a large, region-serving facility that would have skewed our analysis.

Numerically, the largest number of Prop K applications came from Latino areas (117 applications or 5.6 proposals per 100,000 population), trailed by whites (48 applications or 3.7 per 100,000 population; Table 11). In comparison, other types of neighborhoods had very little involvement in Prop K (only 11 total applicants from African American dominated areas, and 10 from Asian-Pacific Islander neighborhoods). The success rates varied sharply by race/ethnic neighborhood type also, with the highest success rates experienced in neighborhoods with 75 percent or more white population (two-thirds of all proposals funded). Areas that were 50-75 percent African American also had a high rate (60 percent success rate). But total numbers of proposals in both of these cases were small ( 9 and 5 respectively). Within Latino-dominated districts, where the numbers of proposals was far larger, there was a direct relationship between success rate and percent Latino, with areas with the highest shares of Latinos having the lowest success rates ( 38 percent versus 65 percent for Latino-dominated areas with less than 50 percent Latino population). Overall, the Latino-dominated area success rate was 45 percent, or 2.2 funded per 100,000 population. 
Table 11. Prop K Funding and Race/Ethnic Neighborhoods.

\begin{tabular}{|c|c|c|c|c|c|c|c|c|}
\hline $\begin{array}{l}\text { Dominant } \\
\text { Race/ } \\
\text { Ethnicity }\end{array}$ & & \# Tracts & $\begin{array}{c}\text { Total } \\
\text { Population }\end{array}$ & $\begin{array}{c}\text { Total } \\
\text { Children }\end{array}$ & $\begin{array}{c}\text { Proposal } \\
\text { Success } \\
\text { Rate }\end{array}$ & $\begin{array}{c}\text { Per Capita } \\
\text { Prop K } \\
\text { Spending }\end{array}$ & $\begin{array}{l}\text { Per Child } \\
\text { Prop K } \\
\text { Spending }\end{array}$ & $\begin{array}{l}\text { Total Prop K } \\
\text { Funding }\end{array}$ \\
\hline \multirow{3}{*}{ Latino } & $>75 \%$ & 188 & 770,471 & 267,703 & $38 \%$ & $\$ 6.26$ & $\$ 18.02$ & $\$ 4,823,302$ \\
\hline & $50-75 \%$ & 217 & $1,019,461$ & 323,896 & $43 \%$ & $\$ 8.77$ & $\$ 27.61$ & $\$ 8,942,194$ \\
\hline & $<50 \%$ & 61 & 281,113 & 70,988 & $65 \%$ & $\$ 3.85$ & $\$ 15.26$ & $\$ 1,082,919$ \\
\hline \multirow[t]{2}{*}{ Total } & & 466 & $2,071,045$ & 662,587 & $45 \%$ & $\$ 7.17$ & $\$ 22.41$ & $\$ 14,848,415$ \\
\hline & $>75 \%$ & 117 & 477,482 & 78,770 & $67 \%$ & $\$ 7.45$ & $\$ 45.13$ & $\$ 3,555,125$ \\
\hline \multirow{2}{*}{ White } & $50-75 \%$ & 127 & 560,472 & 104,403 & $44 \%$ & $\$ 4.96$ & $\$ 26.64$ & $\$ 2,780,869$ \\
\hline & $<50 \%$ & 53 & 258,717 & 52,788 & $14 \%$ & $\$ 1.44$ & $\$ 7.04$ & 371,650 \\
\hline Total & & 297 & $1,296,671$ & 235,961 & $44 \%$ & $\$ 5.17$ & $\$ 28.43$ & $\$ 6,707,644$ \\
\hline \multirow{3}{*}{$\begin{array}{l}\text { African- } \\
\text { American }\end{array}$} & $>75 \%$ & 11 & 49,314 & 13,209 & $0 \%$ & 0 & 0 & 0 \\
\hline & $50-75 \%$ & 31 & 139,455 & 42146 & $60 \%$ & $\$ 5.27$ & $\$ 17.44$ & $\$ 735,015$ \\
\hline & $<50 \%$ & 11 & 45,217 & 9,713 & $25 \%$ & $\$ 26.58$ & $\$ 123.71$ & $\$ 1,201,625$ \\
\hline \multirow[t]{2}{*}{ Total } & & 53 & 233,986 & 65,068 & $36 \%$ & $\$ 8.28$ & $\$ 29.76$ & $\$ 1,936,640$ \\
\hline & $>75 \%$ & 1 & 5,753 & 1,017 & $0 \%$ & 0 & 0 & 0 \\
\hline \multirow[t]{2}{*}{ Asian-PI } & $50-75 \%$ & 7 & 32,180 & 6,331 & $33 \%$ & $\$ 6.22$ & $\$ 31.59$ & $\$ 200,000$ \\
\hline & $<50 \%$ & 14 & 60,011 & 11,266 & $40 \%$ & $\$ 16.79$ & $\$ 89.44$ & $\$ 1,007,609$ \\
\hline Total & & 22 & 97,944 & 18,614 & $30 \%$ & $\$ 12.33$ & $\$ 64.88$ & $\$ 1,207,609$ \\
\hline
\end{tabular}

The result in terms of Prop $\mathrm{K}$ dollars is different, however, since proposals requested different amounts of funding. The most heavily Latino areas received $\$ 6.26$ per capita $(\$ 18$ per child under 18 ), rising to $\$ 8.77$ per capita (and $\$ 27.61$ per child) in moderately Latino dominated areas, and a low of $\$ 3.85$ per capita (and $\$ 15.25$ per child) in Latino-dominated areas where less than 50 percent of the population is Latino. In white-dominated areas, per capita rates ranged from $\$ 7.45$ in areas where 75 percent or more of the population is white, to only $\$ 1.44$ in whitedominated areas with 50 percent or less white population. However, spending per white child tells a different story: in the 'whitest' areas, Prop K spending rose to $\$ 45.13$ per child, while in the moderately white-dominant areas, the rate per child was $\$ 26.64$. (In the less white - but still white-dominant - areas, spending was very low [only $\$ 7.04$ per child] but only one Prop K proposal was funded). African American and Asian-Pacific Islander dominated areas generated very few proposals, and even fewer successful ones, but because their population sizes are comparatively small, their per capita Prop K resources are higher than the first two groups: $\$ 8.28$ and $\$ 12.33$ respectively.

Thus overall, Latino dominated areas generated the highest volume of proposals, and their average per capita Prop K allocation was \$7.17. White dominated areas, with far fewer proposals, averaged $\$ 5.17$ per capita in Prop K funds. African American and Asian-Pacific Islander areas, with relatively small populations and few proposals, nonetheless fared the best in terms of per capita Prop K spending.

\section{Proposition K and City Districts}

With respect to geographic areas, the San Fernando Valley, South Central, East LA, and Harbor Gateway/San Pedro districts were particularly disadvantaged in terms of Prop. K funding. Table 12 provides a comparison of districts (defined according to the City's geographic definitions). 
Table 12. District Comparisons of Prop K Funding.

\begin{tabular}{|c|c|c|c|c|c|c|}
\hline District & $\begin{array}{c}\text { Total } \\
\text { Population }\end{array}$ & $\begin{array}{cc} & \\
\text { Total } \\
\text { Children }\end{array}$ & $\begin{array}{c}\text { Park Acres per } \\
1,000 \text { Population } \\
\text { within } 1 / 4 \text { Mile } \\
\text { Buffer }\end{array}$ & $\begin{array}{c}1990 \\
\text { Poverty } \\
\text { Rate }\end{array}$ & $\begin{array}{l}\text { Per Child } \\
\text { Prop K } \\
\text { Spending }\end{array}$ & $\begin{array}{c}\text { Total Prop K } \\
\text { Funding }\end{array}$ \\
\hline North SF Valley & 653,533 & 193,012 & 31.8 & 9.1 & $\$ 14.25$ & $\$ 2,749,730$ \\
\hline South SF Valley & 703,841 & 169,940 & 17.7 & 9.7 & $\$ 22.85$ & $\$ 3,882,937$ \\
\hline West LA & 390,463 & 61,748 & 167.1 & 8.2 & $\$ 41.68$ & $\$ 2,573,775$ \\
\hline Downtown/Hollywood & 667,525 & 145,001 & 26.4 & 29.4 & $\$ 43.60$ & $\$ 6,322,072$ \\
\hline East LA & 399,382 & 118,221 & 9.7 & 19.1 & $\$ 23.62$ & $\$ 2,791,835$ \\
\hline South Central & 689,539 & 235,483 & 4.1 & 28.5 & $\$ 24.26$ & $\$ 5,713,394$ \\
\hline Harbor/San Pedro & 195,362 & 58,825 & 10.1 & 13.8 & $\$ 23.37$ & $\$ 1,374,996$ \\
\hline Total & $3,699,645$ & 982,230 & 29.1 & 17.2 & $\$ 25.87$ & $\$ 25,408,739$ \\
\hline
\end{tabular}

Table 12 reveals that:

- The North San Fernando Valley received about \$2.7 million total or \$14.25 per resident under age 18 , the lowest rates in the city. With a 1990 poverty rate of only 9.1 percent (compared to the citywide rate of 17.2 percent) and a child poverty rate of 3.3 percent (compared to 6 percent citywide), a share of children just above average, the subarea ranked just above the city's average in terms of park acres per 1,000 population living within a $1 / 4$ mile from a park edge, and had 6 park acres per 1,000 residents.

- South San Fernando Valley received about \$3.9 million or \$22.85 per resident under age 18 , or just under 90 percent of the city average. This area, with a 1990 poverty rate of less than 10 percent, and a share of children just below city average, enjoyed only about 60 percent of the city's average in terms of park acres per 1,000 residents living within a 1/4 mile from a park, and only 3.2 park acres per 1,000 residents.

- The West Los Angeles area, with a low 1990 poverty rate ( 8.2 percent) and by far the lowest concentration of young people in the city, as well as almost 6 times the citywide average in terms of park acres per 1,000 residents living within 1/4 mile from a park edge, and 34.4 park acres per 1,000 residents, received over almost $\$ 2.6$ million or $\$ 41.68$ per resident under age 18 - well above average.

- Downtown/Hollywood, with the highest 1990 poverty rate in the city (29 percent), a lower than average share of young people, 90 percent of the city's average rate of park acres per 1,000 residents living within $1 / 4$ mile of a park edge, and 6.7 park acres per 1,000 population, received $\$ 6.3$ million, or $\$ 43.60$ per resident under 18 , far above average. These figures do not include the funds allocated to the City Department of Recreation and Parks address (which went from there to existing but unidentified parks around the city), and $\$ 9.5$ million for the LA Children's Museum.

- East Los Angeles, with an above average 1990 rate of poverty, a higher than average concentration of kids, only 3.5 park acres per 1,000 population, and a rate of park acres 
per 1,000 residents within $1 / 4$ mile from a park that was only a third of the city average, received $\$ 2.8$ million or $\$ 23.62$ per young person, just under the city average.

- South Central Los Angeles, with a 1990 poverty rate of over 28 percent, and the highest child poverty rate in the city, a far higher than average concentration of young people, only 15 percent of the city's average rate of park acres per 1,000 residents within a 1/4 mile from a park boundary, and a mere 1.2 park acres per 1,000 population overall, received $\$ 5.7$ million, or $\$ 24.26$ per young resident, just under the city average.

- San Pedro, with a below-average poverty rate but high share of young people, had a rate of park acres per 1,000 people living within a 1/4 mile from a park that was only a third of the city's average rate, and 3.7 park acres per 1,000 population. This area received $\$ 1.4$ million - or $\$ 23.37$ per young person, just under the city average.

\section{CONCLUSIONS}

We found that low-income and concentrated poverty areas as well as neighborhoods dominated by Latinos, African Americans, and Asian-Pacific Islanders, endure dramatically lower levels of access to park resources than white dominated areas of the City. In part this result is due to the fact that white dominated areas are located on the edge of the Valley and LA Basin, and thus their residents are close to very large regional parks. Even many white youth, however, have relatively poor access to parks. Those not living in proximity to the City's large open spaces tend to live in lower density subregions, making neighborhood resources less accessible generally. Indeed, across the board, less than 30 percent of the City's population has easy access to park space. Thus a serious problem of park access confronts a vast majority of young people in Los Angeles.

There is simply not enough park space in the City of Los Angeles to provide children and youth reasonable access to parks and open space. This perception motivated the passage of Proposition $\mathrm{K}$, which had the goal of providing additional park space and improving existing park and recreation facilities, and other youth infrastructure.

So far, the focus of Prop K appears to be mostly on the improvement of existing parks, with only a handful of investments in new properties. Areas with the largest shares of young people received half as much Prop $\mathrm{K}$ funding on a per youth basis than areas with the least concentration of children. Higher poverty rate neighborhoods throughout the city did receive more on a per youth basis than areas with lower poverty rates - almost twice as much - but neighborhoods of significant poverty (about 20-40 percent living below the poverty line in 1990) received only a slightly higher allocation per young person than the lowest poverty neighborhoods. Similarly, low-income areas received somewhat more per young person than higher income neighborhoods, but only by about 20 percent. Although what might be identified as the "neediest" subareas of the city - in terms of poverty, highest concentration of young people, and average or below average park accessibility measures -received Prop K funds, more privileged subareas with the highest rates of accessibility, received as much if not more bond 
funds. South Central, the subarea of the city with the second highest poverty rate, highest share of children, and the lowest rate of park acres per 1,000 population within easy access to a park, received only about half as much as affluent West LA in per child Prop K funding, and about the same rate as the more affluent South San Fernando Valley. Similarly, East LA, while slightly better off, received less than 60 percent of West LA's per child funding. Only the Downtown/Hollywood area, the poorest subarea in the city, received as much as West LA on a per youth basis.

This series of findings suggests that the Prop K process in the future should put a high priority on obtaining new park space, and assist low-income and especially predominantly Latino neighborhoods in their efforts to prepare winning proposals. No matter how much work and additional resources are devoted to improving existing parks, those facilities alone cannot provide the access to parks that is so critical to the children and youth of the city. Obtaining new land is a bureaucratically complicated and expensive task, and there is no simple recipe for assembling the urban parcels needed for new facilities. Moreover, in many park-poor areas, there exist no large tracts of land available for park development. However, such areas often contain by a variety of remnant lands - vacant lots, public or utility-owned property, underutilized school sites, streets that are far wider than necessary. This suggests the importance of a creative approach to provision of new parks and open space that utilizes such remnant land resources to provide desperately needed park access for young people, especially in disadvantaged neighborhoods and communities of color. In this way, it may be possible to reweave the fabric of older urban districts of the city to include scattered jewels of greenery and play-space for all Angelenos. 


\section{REFERENCES}

Albrecht, S.L., "Equity and Justice in Environmental Decision Making. A Proposed Research Agenda." Society and Natural Resources 6: 67-72 (1995).

Boocock, S.S., "The Life Space of Children," pp. 16-43 in Suzanne Keller (ed), Building for Women. Lexington, MA: Lexington Books (1981).

Boone, Christopher, and Ali Modarres, "Creating a Toxic Neighborhood in Los Angeles County," Urban Affairs Review 35: 163-187 (1998).

Burgess, Jaqueline, Harrison, Carolyn M., and Limb, Melanie. "People, Parks and the Urban Green: A Study of Popular Meanings and Values for Open Spaces in the City," Urban Studies. 25: 455-473 (1988).

City of Los Angeles, Department of City Planning, 2001, www.cityofla.org/PLN/index/htm.

Conway, Delores, Kahle, Chris, and Wolch, Jennifer. "Pricing the Green City: An Hedonic Analysis of Residential Property Values and Urban Landscape Features Using GIS." Working Paper. Los Angeles: University of Southern California, Lusk Center for Real Estate (2002).

Cunningham, Charles E. and M. Jones, "The Playground: A Confession of Failure?" Built Environment. 25:11-17 (1999).

Diamond, Douglas B., "The Relationship between Amenities and Urban Land Prices." Land Economics. 56:21-32 (1980).

Garvin, Alexander, and Berens, Cayle. Urban Parks and Open Space. Washington, DC: Urban Land Institute, 1998.

Harnick, P. Inside City Parks. Washington D.C.: Urban Land Institute (2000).

Hart, Roger. Children's Experience of Place. New York: Halsted Press (1979).

Loukaitou-Sideris, Anastasia, "Urban Form and Social Context: Cultural Differentiation in the Uses of Urban Parks," Journal of Planning Education and Research. 14:89-102 (1995).

Loukaitou-Sideris, Anastasia, and Orit Stieglitz, "Children in Los Angeles Parks: A Study of Equity, Quality and Children's Satisfaction with Neighborhood Parks," paper presented at the $43^{\text {rd }}$ Annual Association of Collegiate Schools of Planning Conference, Cleveland, Nov, 8-11, 2001.

Medrich, Elliot, Rosen, J., Rubin, Victor, and Buckley, S., The Serious Business of Growing Up. Berkeley: University of California Press (1982). 
Morello-Frosch, Rachel, Pastor Jr., Manuel, and Sadd, James, "Environmental Justice and Southern California's Riskscape: The Distribution of Air Toxics Exposure and Health Risks among Diverse Communities" (Draft Working Paper, 2000).

Nabhan, Gary Paul and Trimble, Stephen The Geography of Childhood: Why Children Need Wild Places. Boston: Beacon Press (1994).

National Recreation and Parks Association, "National Park Land Standards," 4-18-2000. (http://www.ci.cedar-park.tx.us/parks/park_standards.html).

Proshanski, H,. and A. Fabian, "The Development of Place Identity in the Child," in C.S. Weinstein and T.G. David (eds.) Spaces for Children. New York: Plenum Press (1987).

Pulido, Laura, Sidawi, Steve and Vos, Robert O. "An Archaeology of Environmental Racism in Los Angeles." Urban Geography 17: 419-439 (1996).

Schwadron, T., Richter, P., California and the American tax revolt: Proposition 13 five years later. Berkeley \& Los Angeles, California: University of California Press (1984).

Solokow, Alvin D., “The Changing Property Tax and State-local Relations,” Publius 28:165-187 (1998).

Talen, Emily, "Visualizing Fairness: Equity Maps for Planners," Journal of the American Planning Association. 64:22-38 (1998).

Tarrant, Michael A. and Cordell, H. Ken, "Environmental Justice and the Spatial Distribution of Outdoor Recreation Sites: An Application of Geographic Information Systems," Journal of Leisure Research 31:18-31 (1999).

Weiss, Marc, The Rise of the Community Builders. New York: Columbia University Press (1987).

Young, Terrence. "Modern Urban Parks," Geographic Review. 85:535-551 (1995). 




Sustainable Cities Program University of Southern California 927 Hellman Way, PIC 200 Los Angeles, CA 90089-0027 www.usc.edu/dept/geography/ESPE

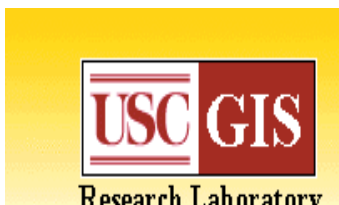

Research Laboratory

GIS Research Laboratory University of Southern California 3620 S. Vermont Avenue, KAP 416 Los Angeles, CA 90089-0255 www.usc.edu/dept/geography/gislab 